\title{
Differential Expression of Two Neuronal Intermediate-Filament Proteins, Peripherin and the Low-Molecular-Mass Neurofilament Protein (NF-L), During the Development of the Rat
}

\author{
Michel Escurat,, Karima Djabali,' Madeleine Gumpel, ${ }^{2}$ François Gros, ${ }^{1}$ and Marie-Madeleine Portier ${ }^{1}$ \\ ${ }^{1}$ Collège de France, Biochimie Cellulaire, 75231 Paris Cedex 05, France, ${ }^{2 H o ̂ p i t a l ~ d e ~ l a ~ S a l p e ̂ t r i e ̀ r e, ~ U n i t e ́ ~ I N S E R M ~ 134, ~}$ \\ 75651 Paris Cedex 13, France
}

The expression of peripherin, an intermediate filament protein, had been shown by biochemical methods to be localized in the neurons of the PNS. Using immunohistochemical methods, we analyzed this expression more extensively during the development of the rat and compared it with that of the low-molecular-mass neurofilament protein (NF-L), which is expressed in every neuron of the CNS and PNS.

The immunoreactivity of NF-L is first apparent at the 25somite stage (about $11 \mathrm{~d}$ ) in the ventral horn of the spinal medulla and in the posterior part of the rhombencephalon. The immunoreactivity of peripherin appears subsequently, first colocalized with that of NF-L. Both immunoreactivities then spread out along rostral and caudal directions, but whereas the immunoreactivity of NF-L finally becomes noticeable in every part of the nervous system, that of peripherin remains localized to (1) the motoneurons of the ventral horn of the spinal medulla; (2) the autonomic ganglionic and preganglionic neurons; and (3) the sensory neurons.

These results demonstrate that, in the neurons that originate from migrating neural crest cells, the immunoreactivities of peripherin and of NF-L become apparent only when they have reached their destination.

The results also show that peripherin is expressed more widely than has been previously observed and that this protein occurs in neuronal populations from different lineages (neural tube, neural crest, placodes) with different functions (motoneurons, sensory and autonomic neurons). The common point of these neurons is that they all have axons lying, at least partly, at the outside of the axis constituted by the encephalon and the spinal medulla; this suggests that peripherin might play a role in the recognition of the axonal pathway through the intermediary of membrane proteins.

Intermediate-filament proteins (IFP) are specifically expressed in different cell types; therefore, they can be considered differentiation markers (reviewed by Lazarides, 1980; Holtzer et al., 1982; Franke et al., 1982) and used as tools to study cell differentiation during ontogeny. Until recently, the IFP specific to the neurons were considered to be the triplet of neurofilament proteins (NFP) of molecular masses 160-210, 140-160, and 68 kDa (Hoffman and Lasek, 1975; Liem et al., 1978; Schlaepfer

Received March 3, 1989; revised Sept. 18, 1989; accepted Sept. 19, 1989.

We thank Drs. C. Sripati and P. Derer for helpful discussions and F. Gosselin for a gift of human keratins. Equipment used in these studies was funded by the $I$ igue Nationale Française Contre le Cancer.

Correspondence should be addressed to Dr. Marie-Madeleine Portier, Collège de France, Biochimie Cellulaire, 11, Place Marcelin Berthelot, 75231 Paris Cedex 05 , France.

Copyright (C) 1990 Society for Neuroscience 0270-6474/90/0300764-21\$02.00/0 and Freeman, 1978), now more generally referred to respectively as high-, middle-, and low-molecular-mass NFP (NF-H, NF-M, and NF-L). These proteins are expressed in most mature neuronal populations belonging either to the CNS or to the PNS; developing neurons generally do not express any of them until they become postmitotic (Tapscott et al., 1981a).

We, however, described another IFP with a molecular weight of about $57 \mathrm{kDa}$, which we had first observed in mouse neuroblastoma cell lines and which was also expressed in rat pheochromocytoma PC12 cell line. Interestingly, in the latter cell line, ${ }^{35} \mathrm{~S}$-methionine incorporation into this protein is greatly enhanced when the cells are differentiated in the presence of NGF (Portier et al., 1984a). Biochemical analyses of extracts from different cell lines, primary cultures, and tissues showed that in the adult, this protein is expressed mostly in neurons from the PNS (Portier et al., 1984b); we then coined for it the word "peripherin." This protein is probably the same as the 60-kDa protein that Liem et al. (1978) have observed in preparations of peripheral nerve filaments; the difference in the molecular masses is probably due to the polyacrylamide gel separations. $\Lambda$ similar protein was observed later by Franke ct al. (1986), Tiercy and Shooter (1986), and Parysek and Goldman (1987) in the rat pheochromocytoma PC1 2 cells by 2-dimensional gel analysis. Then Leonard et al. (1988) characterized NGFinducible mRNAs; one of them was particularly abundant in sympathetic ganglia, and the nucleotide sequence of the corresponding cDNA demonstrated that it coded for an IFP. Comparison of this sequence with those of peripherin CDNAs, prepared from mouse neuroblastoma poly $\left(\mathrm{A}^{+}\right)$mRNAs and cloned in an expression vector (Landon et al., 1989), showed that Leonard's IFP is the same entity as the one we called peripherin (Greene, 1989). The gene structure of rat peripherin (Thompson and Ziff, 1989) confirmed the already prevailing notion that peripherin is a type III IFP (Leonard et al., 1988; Parysek et al., 1988).

Localization of the expression of peripherin, studied either by immunofluorescence (Parysck and Goldman, 1988) or by hybridization in situ (Leonard et al., 1988; Parysek et al., 1988), confirmed our previous results pertaining to the expression of peripherin in neurons from the PNS, but showed that the expression of the gene could also be detected in other neuronal bodies, particularly in motoneurons.

A peripherin antiserum of high specificity and titer, which has been successfully used for immunoscreening of cDNA clones (Landon et al., 1989), prompted us to study the expression of peripherin in situ by immunohistochemistry in order both to confirm our previous results obtained by biochemical methods requiring large amounts of cells or tissues, and essentially to analyze its expression during the development and to compare 

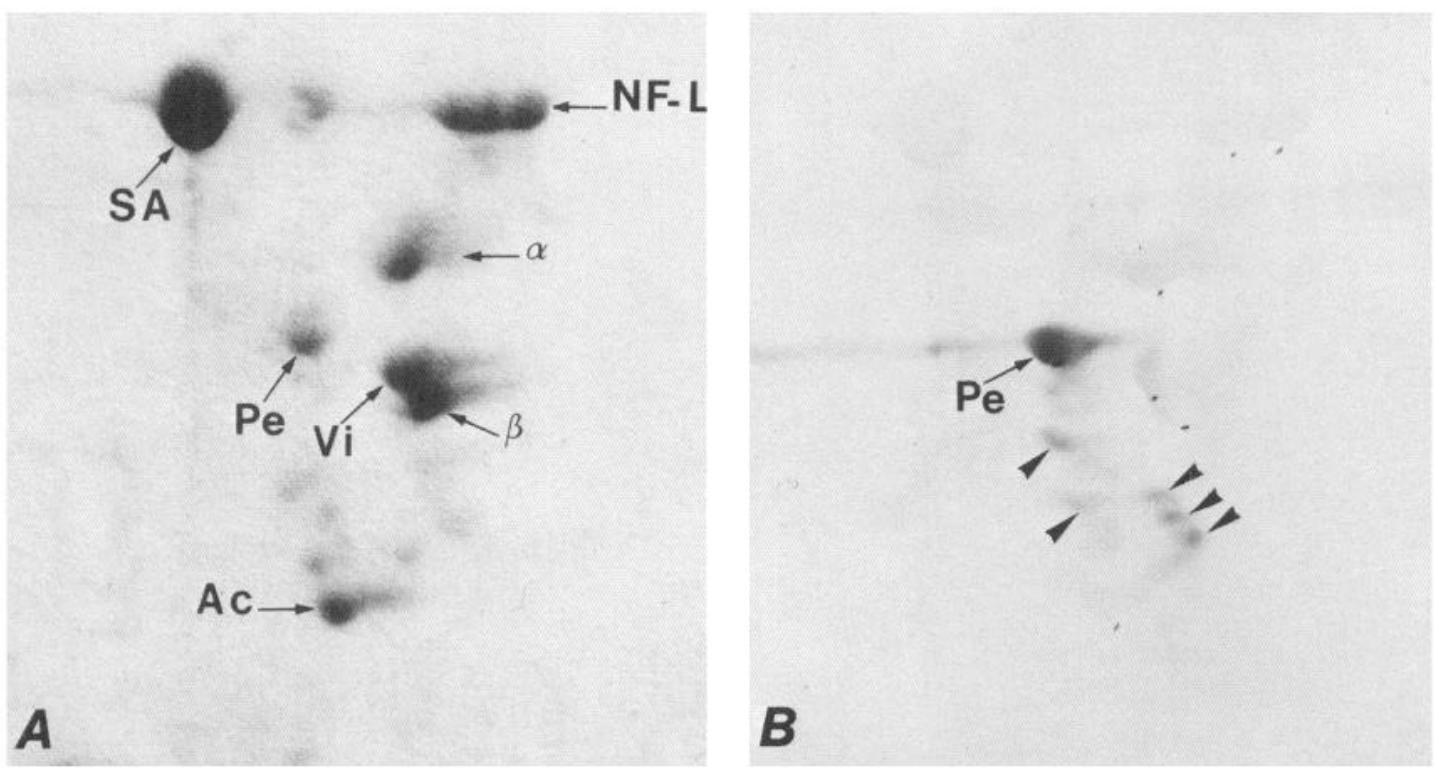

Figure 1. Specificity of the peripherin antiserum. A, Portion of a Coomassie blue-stained 2-dimensional gel ( $8 \%$ acrylamide- $0.09 \%$ bisacrylamide) loaded with an extract from rat sciatic nerve. $B$, Immunodetection of peripherin; the antiserum was used at a 1:100 dilution. Pe, Peripherin; $V i$, vimentin; $N F-L$, low-molecular-mass neurofilament protein; $\alpha, \beta$, tubulin subunits; $A c$, actin; $S A$, serum albumin. Some peripherin degradation products are indicated with arrowheads.

it with that of NF-L. This NFP was chosen particularly because it constitutes the core of neurofilaments (Willard and Simon, 1981; Sharp et al., 1982; Hirokawa et al., 1984; Scott et al., 1985 ) and may be essential to their formation. Peripherin and

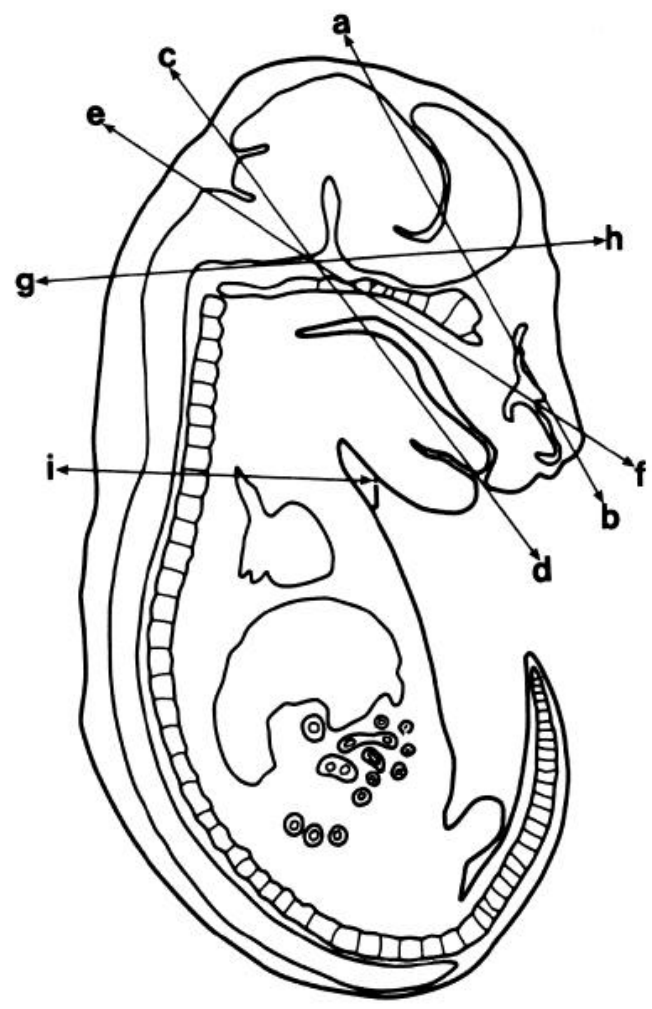

Figure 2. Guidelines representing positions of the transverse sections. A schematic drawing of an E 18 rat embryo with the outlines of sagittal sections of the CNS and a few main organs shows the general orientation of the diverse transverse sections; the diverse orientations may vary slightly according to the age of the embryo and the shape of the head.
NF-L have been shown to be coexpressed in the rat pheochromocytoma PC12 cells (Franke et al., 1986); we also observed this coexpression in primary cultures of rat sympathetic neurons (K. Djabali, unpublished observations). It was thus interesting

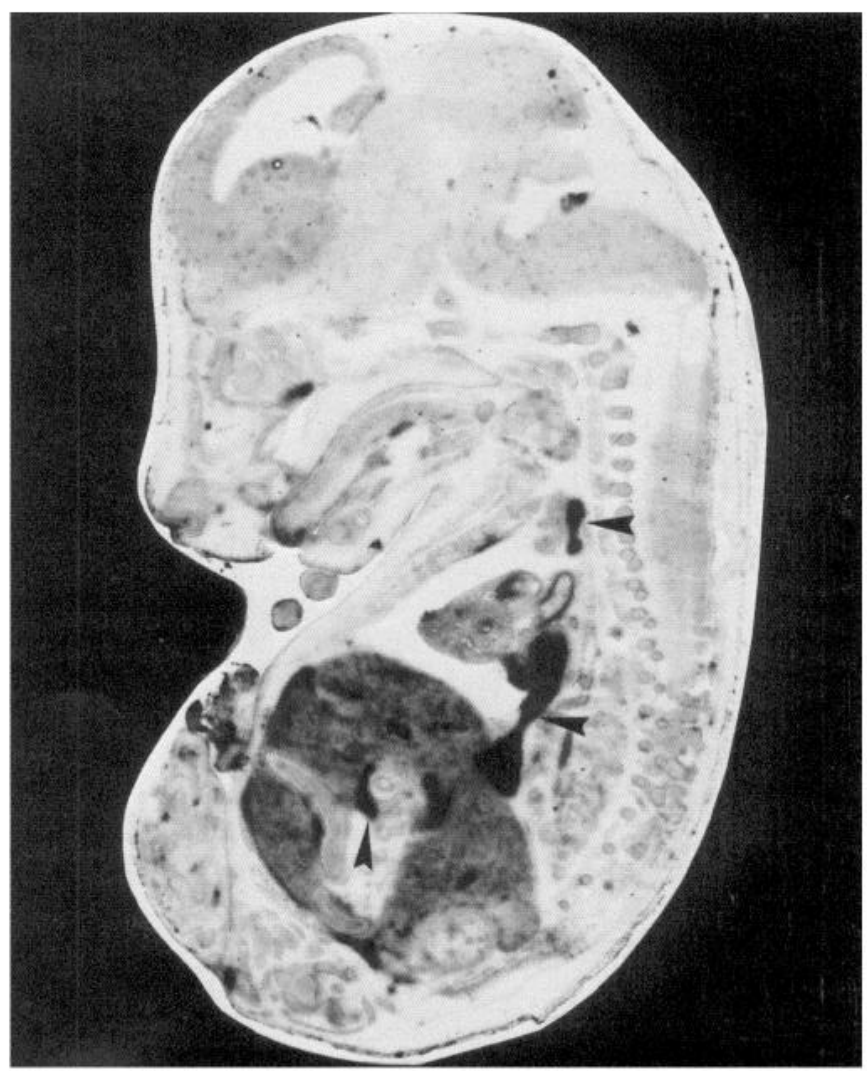

Figure 3. Reactivity of the preimmune serum. The reaction was performed on a parasagittal section at E 15. Some of the decorated blood deposits are indicated with arrowheads. Magnification, $\times 9$. 


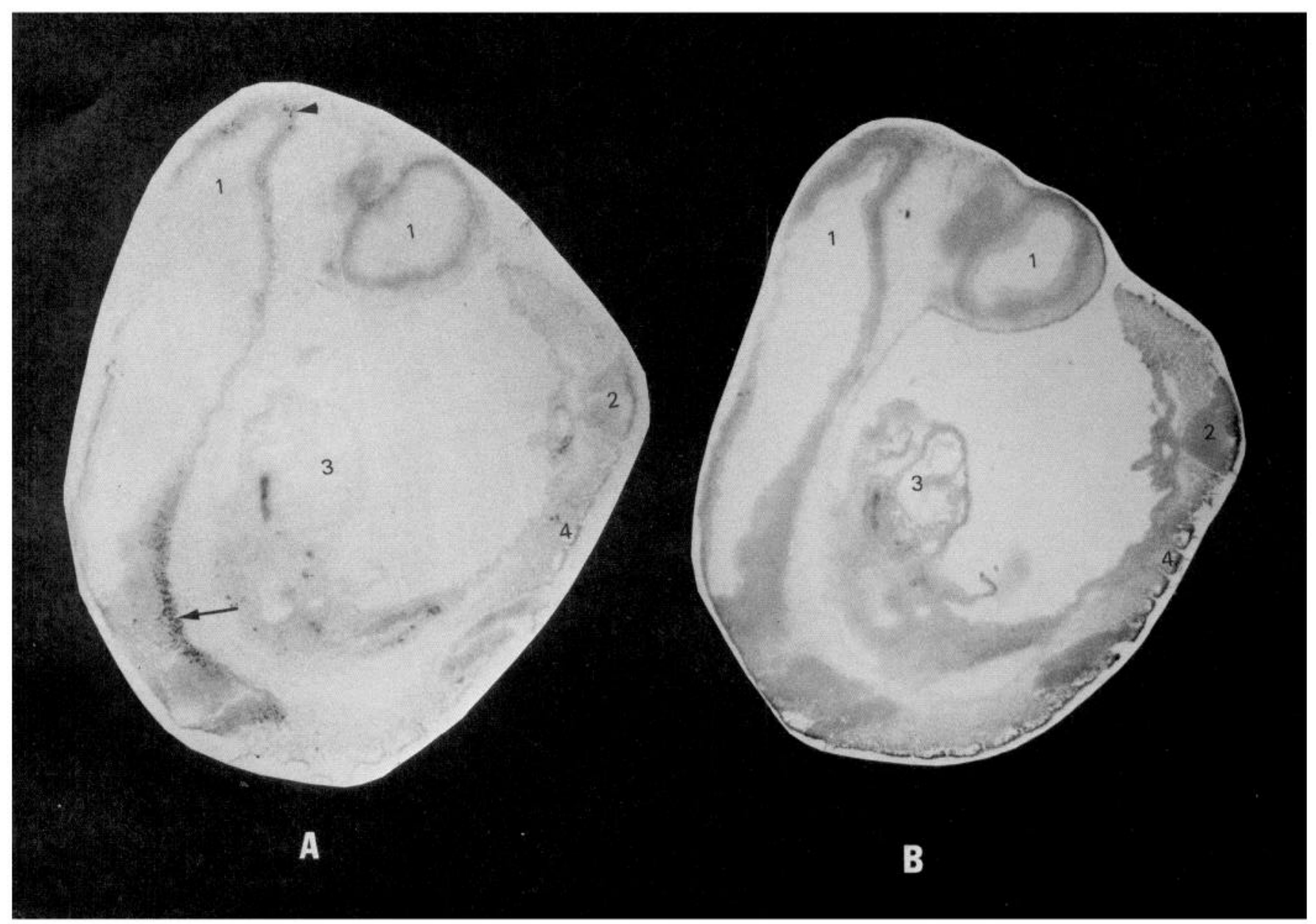

Figure 4. Expression of NF-L in a 25-somite embryo. Distribution of NF-L was revealed using a specific mAb $(A)$, while no reaction of pAb to peripherin could be detected on strictly adjacent parasagittal sections of the same embryo $(B)$. The coiled position of the embryo allows both brain and caudal neurocoel to be seen in the same field. Localization of the expression of the NF-L is restricted to the ventral part of the myelencephalon (arrow) and to some fibers of the trigeminal nerve (arrowhead). The sections are counterstained with methyl green. 1, Central nervous system; 2 , caudal neurocoel; 3 , heart; 4 , a somite. Magnification, $\times 30$. The sections presented here belong to the same embryo; however, the same reaction was also performed on other embryos at the same developmental stage: the results were always similar.

to determine if one of these 2 expressions preceded the other or if they were concomitant. Expression of NFP during the development has already been extensively studied (Cochard and Paulin, 1984; Dahl and Bignami, 1986), and our own observations confirm the results of these studies. As for peripherin, it starts being expressed soon after NF-L but more widely than had been observed previously with biochemical methods. A brief report of this work has already been published (Escurat et al., 1988a). Here, we present a more detailed report demonstrating unambiguously that, whereas the expression of NF-L is a common feature of every neuronal population, that of peripherin is restricted to well-defined sets of neurons. We have also examined the common properties of the neurons expressing peripherin.

\section{Materials and Methods}

Preparation of peripherin antiserum. The insoluble part of a cell extract, from mouse neuroblastoma NIE 115 cells that have been induced to differentiate by treatment with 1-methyl-cyclohexane carboxylic acid (Croizat et al., 1977), was run on 2-dimensional gels as described before (Eddé et al., 1982). The Coomassie blue-stained spot corresponding to peripherin was cut out and pooled together from 100 gels. In order to remove the stain and to concentrate peripherin, about 50 excised spots were loaded on each of two $12.5 \%$ acrylamide slab gels. After migration, 2-cm-wide strips were cut out from the lateral edges of the gels, stained for $15 \mathrm{~min}$ with Coomassie blue, and aligned back into position on the unstained gel. This permitted localization of the peripherin band in the unstained portion of the gel. The band was then excised, washed for 2 hr with 4 changes in sterile phosphate-buffered saline (PBS), and crushed in a glass-Teflon Potter homogenizer. Sterile PBS was then added to render the slurry fluid enough to be pumped through a syringe; it was then divided into portions and stored at $-30^{\circ} \mathrm{C}$. Portions of the slurry were injected intradermally at several points on the back of a rabbit. For the first 2 injections, the gel slurry was diluted $1: 1$ with complete Freund's adjuvant. The injections were given successively at $0,7,16$, $23,30,72$, and $91 \mathrm{~d}$. A week later, the rabbit was bled, and the serum was collected and stored in small portions in liquid nitrogen. The specificity of the antibody was checked by testing the serum against the proteins of different tissue extracts previously separated by 2 -dimensional polyacrylamide gel electrophoresis (isoelectric focusing and nonequilibrium $\mathrm{pH}$ gradient electrophoresis), and transferred onto nitrocellulose membranes. The tissue extracts (mouse neuroblastoma, rat sciatic nerve, chicken gizzard, human sympathetic ganglia, human brain, human epidermis) contained different IFPs (peripherin, vimentin, desmin, glial filamentous acidic protein or GFAP, the triplet of NFP, and keratins). It was thus verified that the polyclonal antibody (pAb), raised as described above, recognized exclusively peripherin. On nitrocellulose membranes, reaction against peripherin was observed even at a dilution of 1:10,000. We present here (Fig. 1) the immunodetection of peripherin among the proteins of rat sciatic nerve, the antiserum being then diluted 


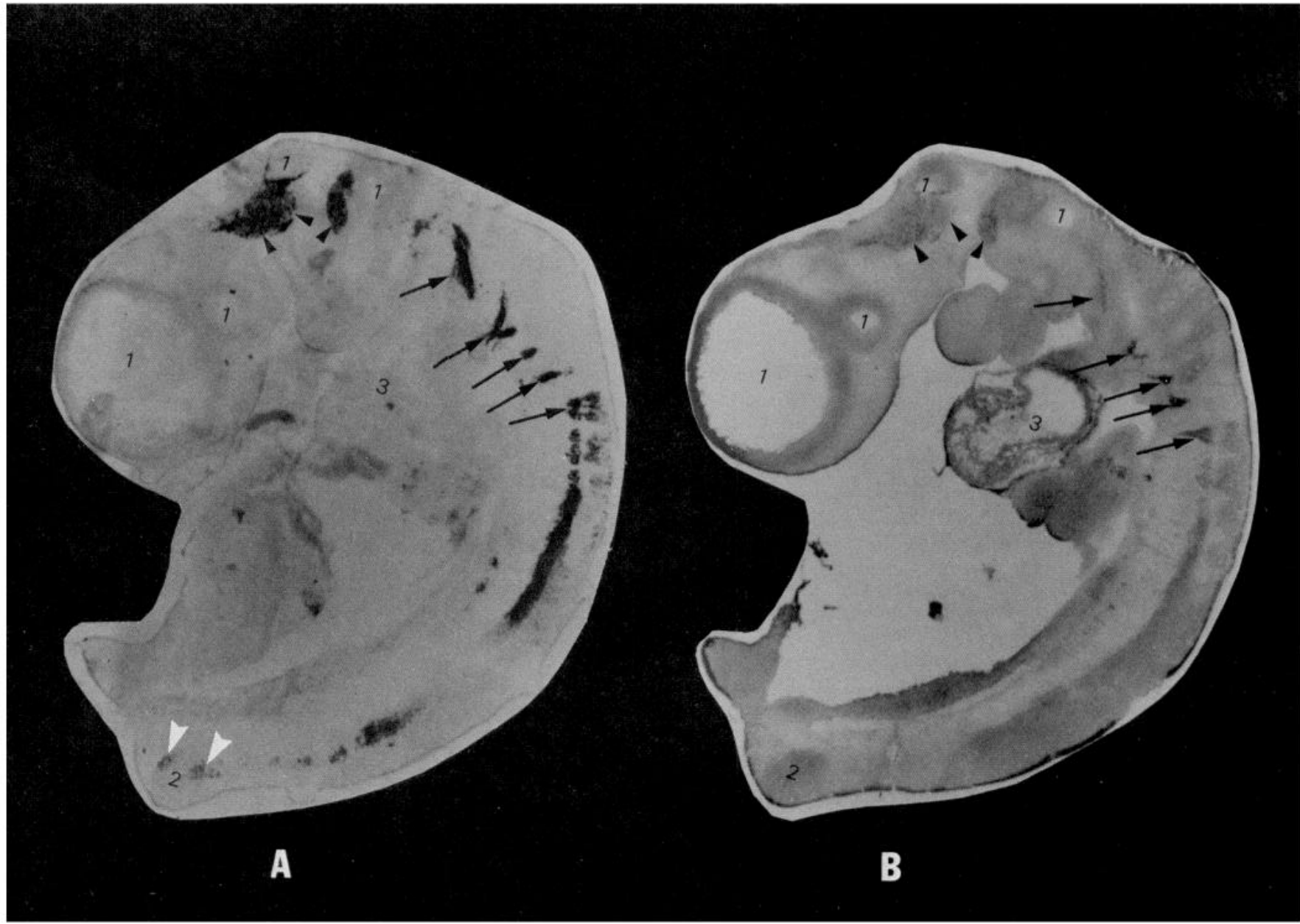

Figure 5. Expression of NF-L and peripherin in a 34-somite embryo. Distributions of NF-L $(A)$ and of peripherin ( $B$ were revealed as in Figure 4 on strictly adjacent sections of the same embryo. The coiled position of the embryo still allows both brain and caudal neurocoel to be seen in the same field as in Figure 4. Immunoreactivity of NF-L is apparent in the anterior dorsal root ganglia; it is detected caudally in the ventral part of the spinal cord (white arrowheads); immunoreactivity to peripherin is colocalized with that of NF-L in the anterior part (arrows). The trigeminal nerve is well developed and decorated by both antibodies (arrowheads). 1, 2, 3, As in Figure 4. Somites are not clearly delineated on these photographs. Magnification, $\times 30$. See note in the legend of Figure 4.

as used subsequently on sections; the serum recognized only peripherin and minor species of lower apparent molecular mass, which frequently accompany peripherin and which could represent its degradation products (Aletta et al., 1988). Another proof of its specificity is that sequence analyses of cDNA clones immunodetected with this same antibody demonstrated that they were specific to peripherin (Landon et al., 1989).

For immunohistochemistry on sections, 1:100 dilution was routinely used.

Origin of the other antibodies. The monoclonal anti-NF-L neurofilament protein $(\mathrm{mAb})$ was from Amersham (U.K.). It was used at a dilution of 1:30.

Anti-rabbit IgGs (Biosys, France), diluted 1:10, were used as second antibody and detected with a peroxidase-antiperoxidase complex prepared in rabbit (Miles) and diluted 1:100.

Peroxidase-labeled anti-mouse IgGs (Amersham), diluted 1:30, were used as the second antibody in the case of the mAb.

Preparation of embryos. Wistar rats were mated at night; the following morning was considered as gestational age $0.5 \mathrm{~d}$; embryos were dated according to the number of somite pairs (which we shall only call somites) for the earliest ones and to the gestational age for the others. The embryos were removed from the uterus, freed of the extraembryonic membranes, bled as much as possible through the umbilical cord, and immersed for $2 \mathrm{hr}$ at $4^{\circ} \mathrm{C}$ in Soerensen buffer (phosphate buffer, $0.1 \mathrm{M}$, pH 7.3) containing sucrose at a concentration of $8 \%$ for the embryos ranging from 15 somites to $14 \mathrm{~d}$ and $10 \%$ for the others.

Early embryos ( 15 somites to E 16) were embedded in cryomoles and
OCT and the oldest ones in OCT only, before freezing in isopentane cooled with liquid nitrogen.

Postnatal animals were decapitated; the heads were then treated as the older embryos.

Ten-micrometer sections were cut with a Reichert-Jung cryostat through different levels, so that every important part of the nervous system and every sense organ were sectioned; it is also worthwhile mentioning that even in the oldest embryos sections were cut on the whole organism so as to retain the connections between the neurons and their respective targets. As depicted in Figure 2, sagittal and differently orientated transverse sections were thus made systematically; for instance, the earliest embryos (15-44 somites) were sectioned sagittally from the outer surface to the median plane. For each stage, peripherin and NF-L protein expressions were investigated on strictly adjacent sections from the same embryo, which thus presented similar aspects of the different tissues.

Sections were mounted on gelatin-coated slides, air-dried for $30 \mathrm{~min}$ at room temperature, and fixed with $80 \%$ methanol at $-20^{\circ} \mathrm{C}$ for 10 $\mathrm{min}$; they were washed 3 times, each for $5 \mathrm{~min}$, with Tris- $\mathrm{HCl}, 0.05 \mathrm{M}$, $\mathrm{pH} 7.2$, containing $0.9 \% \mathrm{NaCl}$, and then incubated overnight at $4^{\circ} \mathrm{C}$ with the polyclonal or the monoclonal antibody.

The reaction of the monoclonal antibody was visualized with peroxidase-conjugated goat anti-mouse Ig (Amersham), whereas the pAb was first reacted with anti-rabbit Ig (Biosys) and then revealed with the peroxidase-antiperoxidase complex (Miles). After three 5-min washings, peroxidase was detected with DAB. 

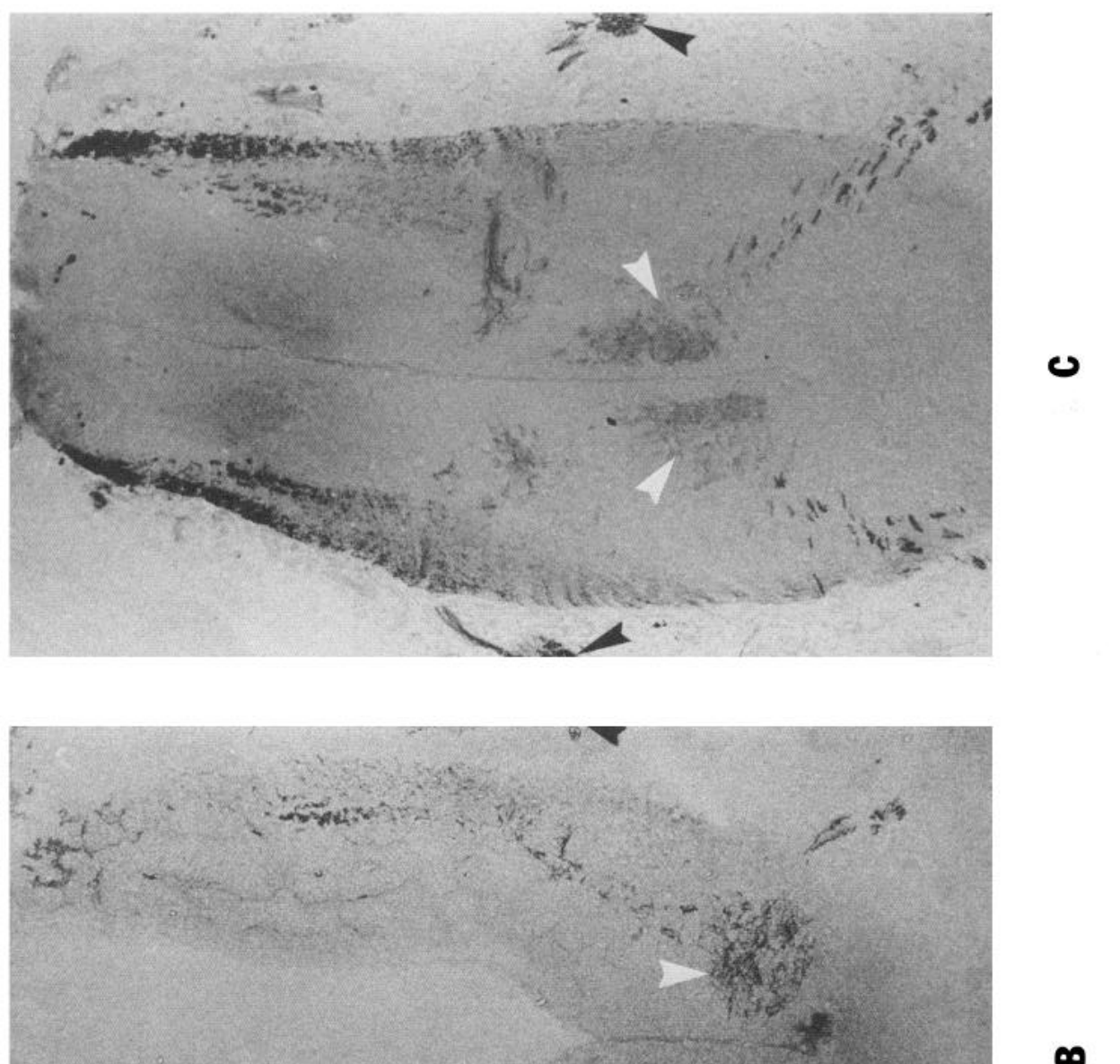

士. 目

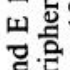

额

9

뚠드.

조임

떠옳

응. 져

등

-

웡

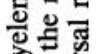

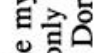

$\neq 0$

을

突

政

递范

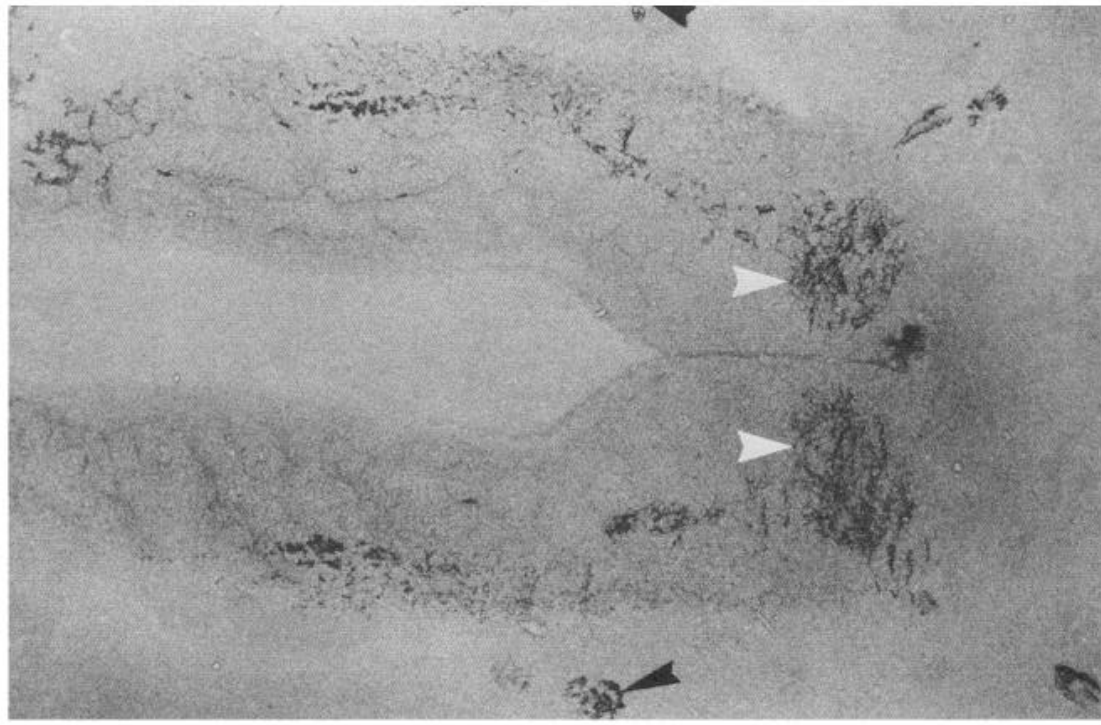

究

웅

ธํㅠ를

उु

ङ羊

는.

需 웅

튼 증

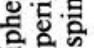

$\boldsymbol{\infty}$

웡

砳产

홍

势

롤

究

긍

융

형하

을

एक

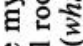

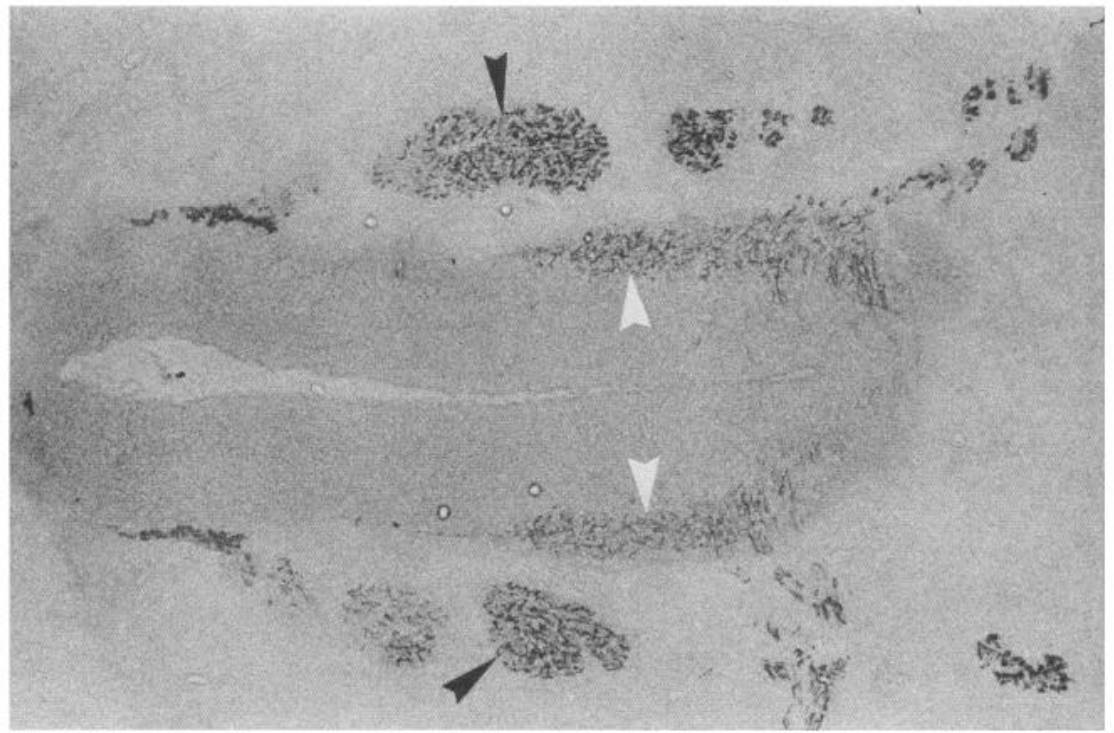

푤

동일

동멸

능

을

둥

휴요

蛘.

-

$<\quad 0$ 婇 ㅇ․웅 跑

드응

년영

돌 ० 证 㓠范 
Sections were then counterstained with methyl green $(0.01 \%)$ for $0.5-$ $2 \mathrm{~min}$ and rinsed with water. After dehydration in ascending ethanol, the sections were coverslipped with Depex (Serva). Preparations were examined with a light microscope and photographed at several magnifications.

Figure 3 shows the reactivity of the preimmune serum on a section of a 15-d-old embryo (E 15). Only blood deposits are decorated; this cross-reaction could be attributed to endogenous peroxidase, and depends on the amount of blood that remains in the animal after bleeding.

Preparation of tissue extracts. Dorsal root ganglia and spinal cord were dissected out from 14-, 18-, and 21 (prenatal)-d-old embryos (10 for the dorsal root ganglia, 3 for the spinal cord) and incubated for 4 $\mathrm{hr}$ at $37^{\circ} \mathrm{C}$ in $200 \mu$ l Ringer's buffer $(\mathrm{NaCl} 0.154 \mathrm{M}, \mathrm{KCl} 5.6 \mathrm{~mm}, \mathrm{CaCl}$ $2.8 \mathrm{~mm}$, NaHCO $1.8 \mathrm{~mm}$, glucose $0.1 \%$ ) in the presence of $250 \mu \mathrm{Ci}^{35} \mathrm{~S}$ methionine. They were homogenized as described before (Portier et al., 1984b) and treated immediately for isoelectric focusing (O'Farrell, 1975).

Polypeptide analysis. Proteins were separated by 2-dimensional gel electrophoresis according to the procedure of O'Farrell (1975), modified as described previously (Eddé et al., 1982). Gels were stained with Coomassie blue and autoradiographed on Kodak Industrex films. Cytoskeletal proteins, identified by their electrophoretic features and by peptide mapping by limited proteolysis, were detected by the IFA antibody elicited by Pruss et al. (1981), which recognizes the epitope common to every IFP located at the carboxy-terminal end of the rod domain.

\section{Results}

\section{Expression of peripherin and of NF-L in motoneurons}

Immunoreactivity, undetectable for both proteins at early stages during neural tube closure (here, for instance, at the 15-somite stage), is first seen for NF-L in 25-somite embryos (Fig. 4). Since the immunoreactivity was not detected in the 15-somite ones, it probably started between these 2 stages as described in the mouse (Cochard and Paulin, 1984). This expression is first restricted to areas located in the spinal cord, immunoreactive cells being localized near the outermost borders of the neuroepithelium (Fig. 4); it is also visible in the rhombencephalon particularly at the level of emerging fibers which probably correspond to the trigeminal nerve.

The expression of NF-L was rapidly followed by that of peripherin, which was similarly localized as seen clearly on sections from 34-somite embryos (Fig. 5). In subsequent stages, positive cells located at the outer border of the spinal cord migrated toward the center at the border between gray and white matter, when thickening of the latter takes place. Expressions of both peripherin and NF-L are colocalized in the ventral horn neurons. Appearance of immunoreactivity of the cell bodies was accompanied by that of the axons present in the ventral roots. The transverse sections from 44-somite embryos displayed in Figure 6 summarize these results; since the staining with either antibody was similarly localized, only the results for the peripherin antiserum are shown.
From the 25-somite stage onward, the extension of NF-L immunoreactivity was rapid and occurred progressively in rostral and caudal directions appearing in neuronal populations other than motoneurons and reaching the most caudal part at the following stage that we have examined (34-somites), but the telencephalon only between E 18 and E 19 (Fig. 7) and the olfactory bulb after birth. The expression of NF-L, first localized only in cell bodies, expanded with the development of interneuronal connections and axonal fascicles.

By contrast, the expression of peripherin remained localized to the neurons where it is first expressed, whose pattern of migration demonstrates that they are motoneurons, and consequently to their axons; the expression in the motoneurons progressed caudally following that of NF-L; it did not develop further rostrally (Fig. 7).

Quantitatively, the expression of peripherin in the spinal cord is very low, as can be seen from the autoradiograms in Figure $8, A, C, E$. The 2-dimensional polyacrylamide gels were loaded with ${ }^{35}$ S-methionine-labeled proteins from E 14, E 18, and E 21 spinal cords, Coomassie blue-stained, and then autoradiographed; clearly, the amount of peripherin remains very low compared to that of NF-L throughout the development. The difference between the degree of expression of these 2 proteins is even more obvious in the adult (Fig. $8 G$ ). In this case, the gel was only Coomassie blue-stained and the amount of peripherin is so low that it could not be detected unambiguously.

\section{Expression of peripherin and of NF-L in the sensory neurons}

Results are summarized in Table 1.

\section{Neurons originating from the neural crest}

Fibers constituting the different branches of the trigeminal nerve belong to neurons from diverse origins: either the neural crest or a placode for the sensory neurons and the neural tube for the motor ones. Consequently, we describe here the trigeminal nerve because we could not distinguish the origin of its fibers.

NF-L immunoreactivity first appeared in the trigeminal nerves at the 25-somite stage, at the same time as in the rostral extremity of the spinal cord (Fig. 4); it could have becn first related to the axons from motoneurons. Here also, the expression of NF-L was followed by that of peripherin at the 34-somite stage (Fig. 5). The development of the trigeminal nerves could be followed easily at every stage because of their large size; they become prominent with their 3 main branches: ophthalmic, maxillary, and mandibular (Fig. 9). Vibrissae are innervated (Fig. 10) by fibers from the maxillary branch. In the tongue,

Figure 7. Comparative expression of NF-L and of peripherin during the development of the rat embryo. Parasagittal [E $14(A, B)$, E $16(C, D)$ ] and midsagittal $[\mathrm{E} 19(E, F)$ ] sections were immunostained with the same antibodies as in the preceding figures: the mAb to NF-L $(A, C, E)$ and the pAB to peripherin $(B, D, F)$. Note the increasing importance of NF-L expression while peripherin expression remains localized to the neuronal populations where it first appeared and where it is colocalized with that of NF-L. The tectum (arrows on $E$ and $F$ ), in which fibers project from part of the ganglion cells of the temporal periphery of the retina, is immunoreactive to both antibodies. On the contrary, the olfactory nerve and the sections of olfactory fibers under the olfactory epithelium are immunoreactive only with the pAb antibody to peripherin. $G$ and $H$ are transverse sections of the head of a 7-d-old rat through $a-b$ in Figure 2; $G$ displays the immunoreactivity to the mAb to NF-L and $H$ to the pAb to peripherin; the difference between the extensions of the expressions of the 2 proteins under study is evident; in the CNS, only sections of afferent fibers into the cerebellum (6) and the tectum (black arrowheads) are decorated by the pAb to peripherin (arrows). The retina is decorated by both antibodies, as are the fibers belonging to the trigeminal nerve along the nasal cavities. 1, Nasal cavity and olfactory nerve (double arrow in $D$ and arrowhead in $F$ ); 2 , olfactory bulb; 3 , telencephalon; 4 , diencephalon (dorsal thalamus); 5 , mesencephalon; 6 , cerebellum; 7 , myelencephalon; 8 , spinal cord; 9, dorsal root ganglia; 10 , vertebrae; 11 , tongue; 12 , trachea; 13 , heart; 14 , liver; 15 , intestinal loops; 16 , eyes; 17 , upper incisors; white arrowheads, vibrissae. Magnifications, $\times 14(A$ and $B) ; \times 9(C$ and $D) ; \times 4(E-H) . E$ and $F$, Courtesy of Académie des Sciences (Escurat et al., 1988a). See note in the legend of Figure 4. 


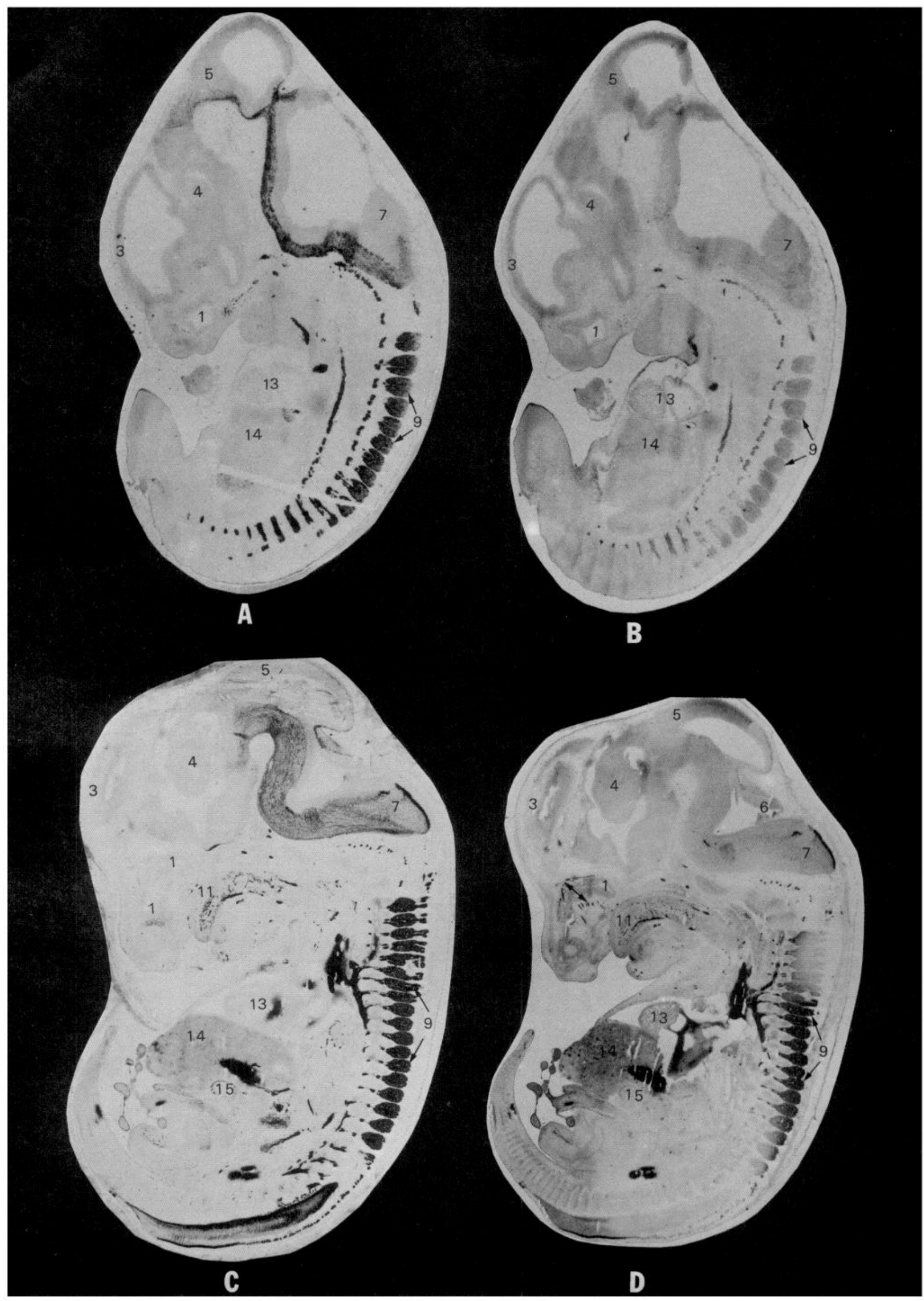




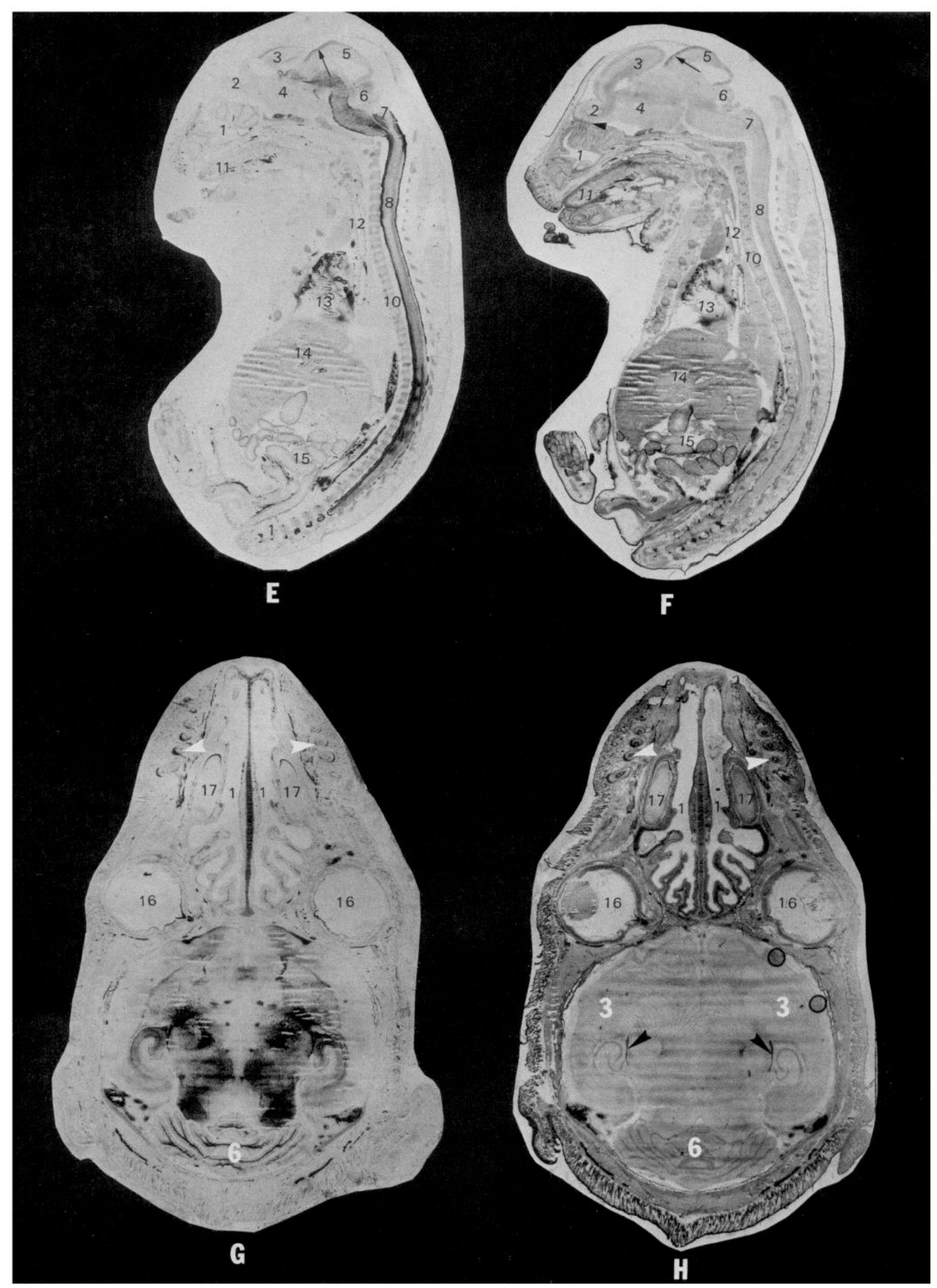




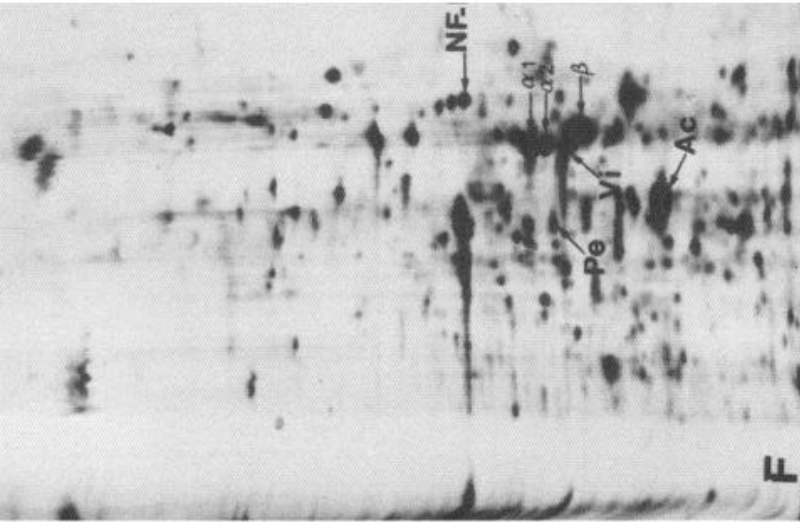
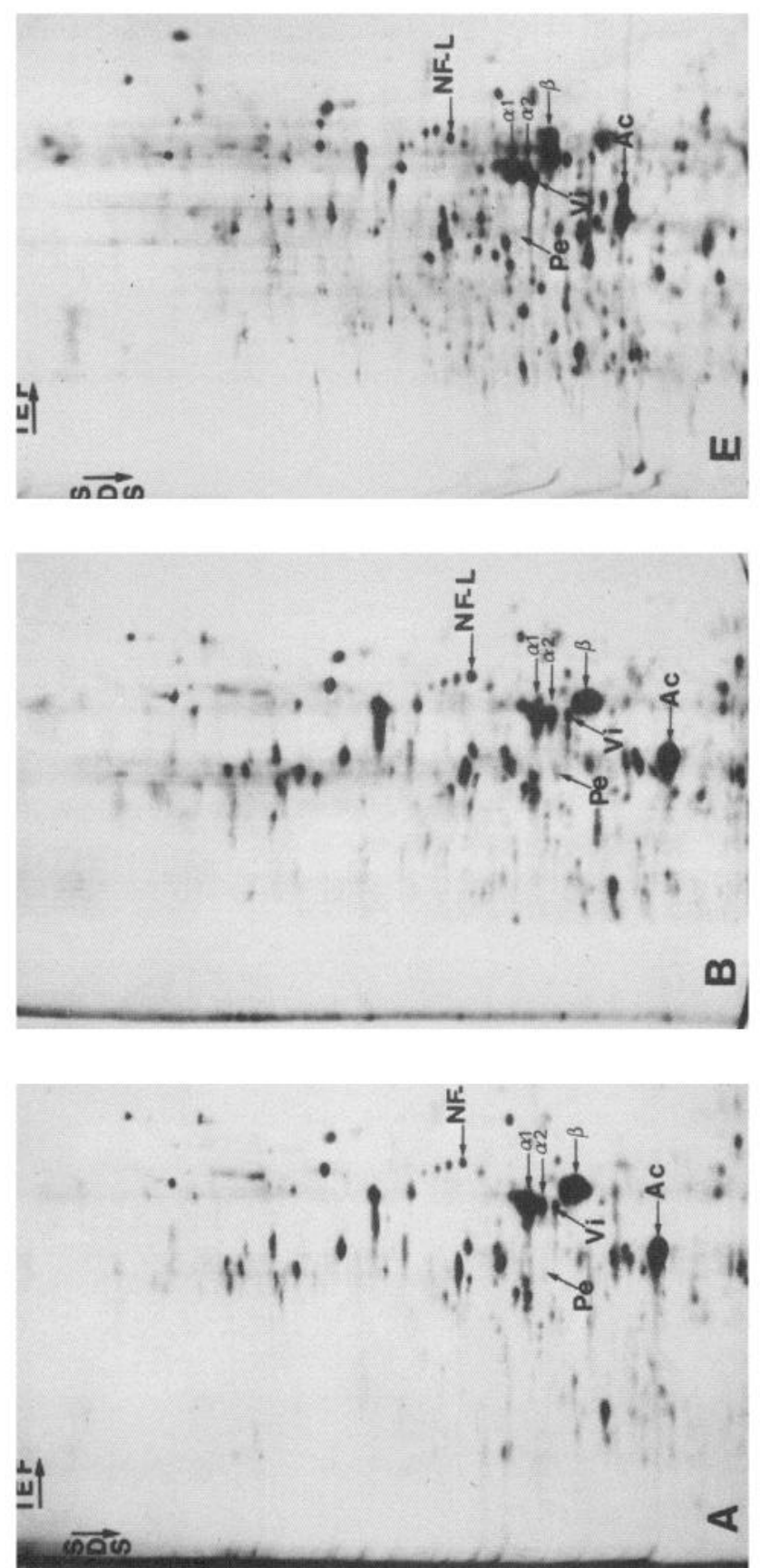
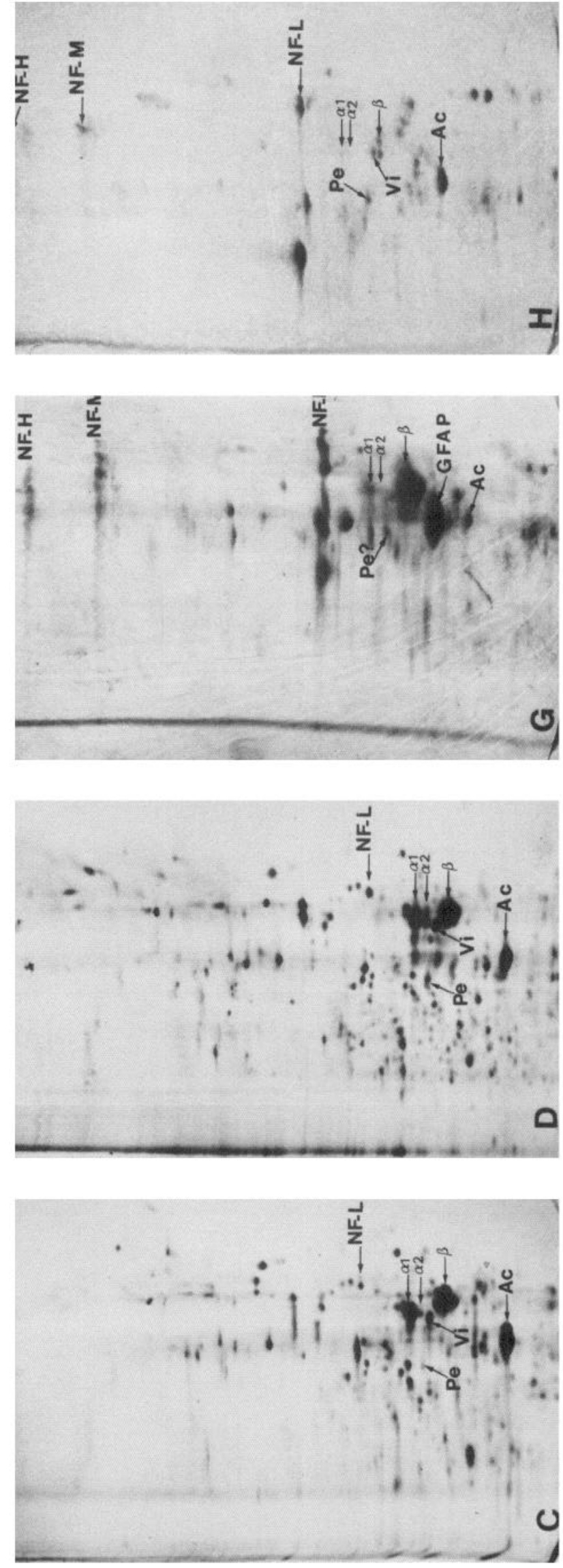
fibers reactive to both antibodies are noticeable at $\mathrm{E} 15$ and become quite visible at $\mathrm{E} 16$ (Fig. 7, C, D); they probably belong to the lingual nerve arising from the mandibular branch.

As for the dorsal root ganglia, immunoreactivity appeared for both antibodies at the 34-somite stage at the cervical and thoracic levels in axons as well as in cell bodies (Fig. 5); both immunoreactivities then spread out along the caudal direction, every dorsal root ganglion being decorated by both antibodies at $\mathrm{E} 14$ (Fig. 7, $A, B$ ). Development of the peripheral nerves was concomitant; the brachial plexus, as well as the lumbosacral one, were clearly seen in the 44-somite stage; they are also well seen at $\mathrm{E} 14$ on longitudinal sections parallel to the median plane (Fig. 7, $A, B$ ). The dorsal root ganglia are very large compared to the size of the embryo (Fig. 7, $A, B$ ). From comparison of magnifications of dorsal root ganglia from 1-week-old animals, it can be seen that the smallest neurons are more immunoreactive to antiperipherin than the largest ones, which seem better decorated by anti-NF-L (Fig. 11).

Quantitatively, the biochemical data of Figure 8, showing 2-dimensional gels loaded with ${ }^{35} \mathrm{~S}$-methionine-labeled proteins from dorsal root ganglia excised at E 14, E 18, and E 20 (Fig. $8, B, D, F)$ from the same embryos as for the spinal cords, indicate that the amounts of NF-L and peripherin, very low at E 14, increase afterward (E 18) and seemingly reach stable levels rapidly (at E 20). The difference between the levels of expression of peripherin and NF-L in the adult are conspicuous even after Coomassie blue staining (Fig. 8H).

\section{Neurons originating from the placodes}

Olfactory neurons. Immunoreactivity of peripherin was first detected in the olfactory nerves at $E 15$. The expression of peripherin was followed up to 1 week after birth, when the bone tissue of the skull can still be sectioned (Fig. 12). The olfactory neurons are only slightly stained, in contrast to the corresponding fibers circulating under the epithelium whose sections are equally well seen either on sagittal or on transverse sections. On the contrary, immunoreactivity corresponding to NF-L did not appear at any time during development in the olfactory nerve fibers (Fig. 12).

Neurons of the acoustic ganglia. Immunoreactivities for both NF-L and peripherin can be revealed in acoustic ganglia at $\mathrm{E}$ 13 (Fig. 13, $A, B$ ). No such immunoreactivities are detected in the otic vesicle even in the following stages. At $7 \mathrm{~d}$ after birth, when it is still possible to cut sections without damaging the tissues, the vestibular ganglia is clearly seen on a transverse section of the head (Fig. 9, $E, F$ ) and on photographs at higher magnification of parts of transverse sections oriented differently (Fig. 13, C, D).

\section{Neurons originating from the neural tube}

Both immunoreactivities are revealed in the retina at E 15 and in the optic nerves $1 \mathrm{~d}$ later. Some immunoreactivity was clearly visible in the tectum with both antibodies at E 14; it should correspond to the projections of the optic fibers (Fig. 7, E, F).

Figure 9, $G, H$, and Figure 14 show that both retina and optic nerves are immunoreactive to both antibodies. The expressions of the IFPs under study are definitive; 2-dimensional polyacrylamide gel analyses have also revealed the presence of biochemically detectable quantities of these proteins in human and guinea pig retinas (not shown).

\section{Expression of peripherin and NF-L in the autonomous nervous system}

Both immunoreactivities were detected in the sympathetic ganglia at the same time as in the dorsal root ganglia (34-somite stage). Antibody decoration of ganglia in the trunk is shown in Figure 15, $A, B$, at the 44-somite stage; it appeared in sections of fibers innervating intestinal loops, liver, trachea, and bronchi according to the developmental stage of the organ (Fig. 7, $E$, $F$ ); Figure $15, C, D$, shows photographs at higher magnification of the innervation of intestinal loops.

From sections realized on 1-month-old animals, it is clear that peripherin and NF-L are present in autonomic preganglionic axons synapsing into sympathetic ganglia (Fig. $15, E, F$ ) and consequently in the corresponding neuronal cell bodies located in the intermediolateral cell column of the spinal cord.

Quantitatively, it was not possible to collect enough material from the rat. However, the analysis of proteins from an extract of adult human sympathetic ganglia on 2-dimensional gels clearly demonstrated that peripherin is quantitatively the most important IFP in sympathetic neurons (Escurat et al., 1988b).

\section{Discussion}

The expressions of peripherin and of NF-L have been studied in detail during the development of the rat. This was made possible by the choice of sections comprising every neuroncontaining tissue and the tracts of the fibers. Since our earlier studies on peripherin expression (Portier et al., 1984b) relied on biochemical methods requiring large quantities of materials, the conclusion that peripherin was specific to the peripheral ncrvous systcm originating from the neural crest could be considered incomplete; therefore, analysis at cellular level became imperative. As might be expected, the results reported here not only supply further information, but also raise some points not considered before.

The comparison of the expressions of peripherin and NF-L allows us to claim that, whereas NF-L is a general marker for neurons, peripherin, on the contrary, is expressed only in welldefined neuronal populations. Regarding NF-L expression, our results are in general agreement with those already described in rat (Raju et al., 1981; Bignami et al., 1982), chick (Bignami et al., 1980; Tapscott et al., 1981a, b), and mouse (Cochard and Paulin, 1984) embryos. As to peripherin expression, the fact that it follows closely that of NF-L demonstrates that it is expressed postmitotically as NFP (Tapscott et al., 1981a) in most

\section{$\leftarrow$}

Figure 8. Analyses of proteins of dorsal root ganglia and spinal cord during the development. Proteins were separated by 2-dimensional gel electrophoresis and visualized by autoradiography. First dimension $(I E F)$, Isoelectrofocusing between $\mathrm{pH} 6.75(\mathrm{OH}-)$ and $\mathrm{pH} 4.25(\mathrm{H}+)$. Second dimension $(S D S)$, Slab gel composed of a $2-\mathrm{cm}$-long stacking gel (5\% acrylamide; $0.125 \mathrm{~m}$ Tris $\mathrm{HCl}, \mathrm{pH} 6.8 ; 0.1 \%$ SDS) and a $24-\mathrm{cm}-\mathrm{long}$ separating gel $(8 \%$ acrylamide; $0.375 \mathrm{M}$ Tris $\mathrm{HCl}$, pH $8.8 ; 0.1 \% \mathrm{SDS}) .2 \times 10^{6}$ counts $/ \mathrm{min}$ of TCA-precipitable ${ }^{35} \mathrm{~S}$-methionine-labeled proteins were loaded on each first-dimensional gel. Exposure time for the autoradiography was $8 \mathrm{~d}$. $A c$, Actin; $\alpha 1, \alpha 2, \beta$, tubulin subunits; $V i$, vimentin; Pe, peripherin; $N F-L, N F-M, N F-H$, neurofilament proteins. $A, C, E,{ }^{35}$ S-methionine-labeled proteins from spinal cords of E 14, E 16, E 21 embryos, respectively; $B, D, F,{ }^{3 s}$ S-methionine-labeled proteins from dorsal root ganglia of the same embryos, respectively; $G, H$, Coomassie blue-stained proteins from, respectively, the spinal cord and the dorsal root ganglia of adult rats. 


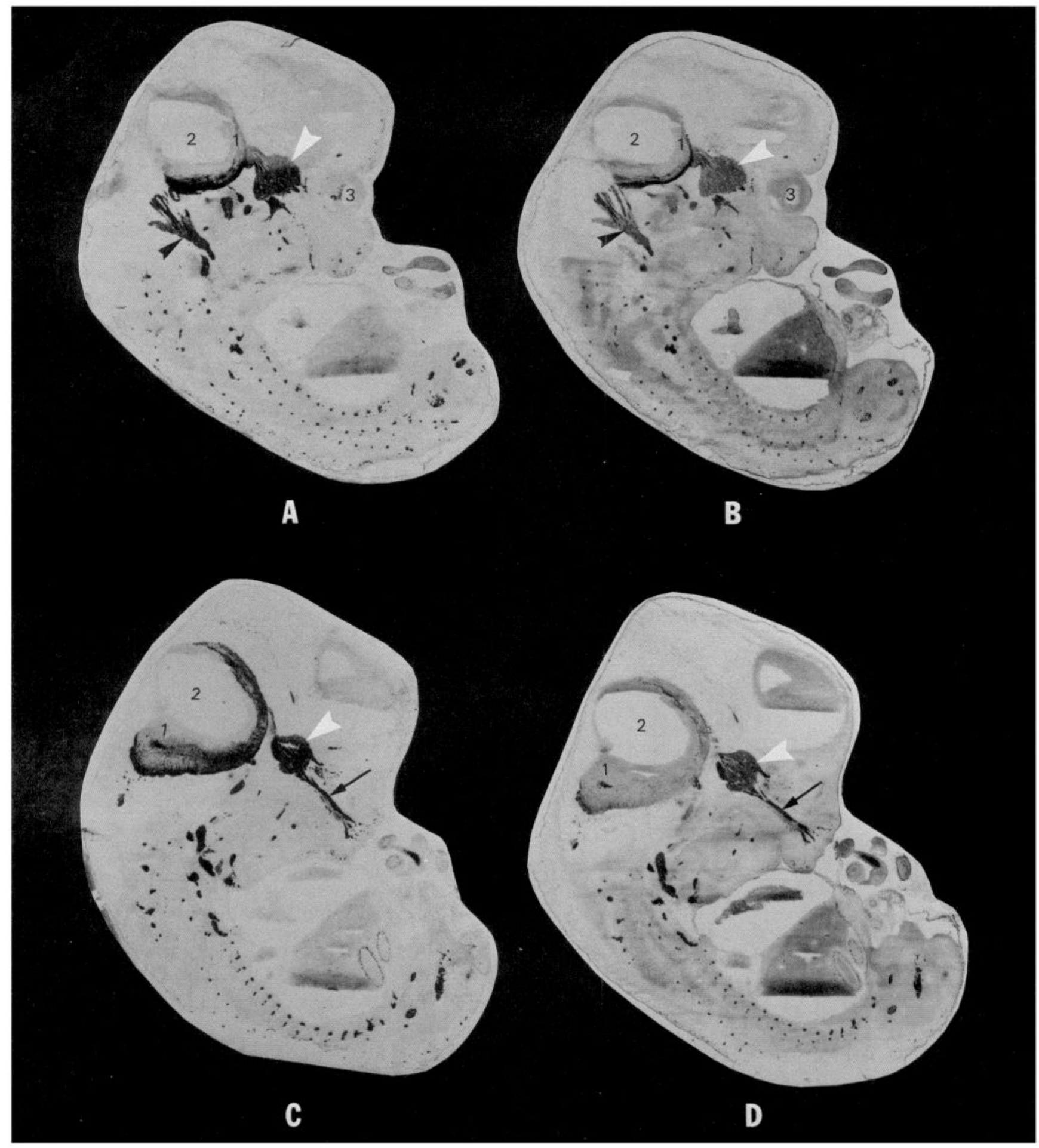

Figure 9. Expression of NF-L and peripherin in the trigeminal nerve. $A, C$, Parasagittal sections of $\mathrm{E} 15$ embroys decorated with the mAb to NF$\mathrm{L} ; B, D$, sections strictly adjacent, respectively, to $A$ and $C$ decorated with the pAb to peripherin. $E-H$, Transverse sections (through $c-d$ in Fig. 2 for $E$ and $F$ and through $a-b$ for $G$ and $H$ ) of the head of a 1-week-old rat. 1, Myelencephalon; 2, myelocoel; 3, eye (retina and optic nerve are decorated by both antibodies in $G$ and $H$ ); 4 , cerebellum; 5 , tongue; 6 , upper incisors; 7, nasal cavity; 8 , telencephalon. White arrowhead, Trigeminal nerve V cranial ganglia or semilunar ganglia (note their predominance); single black arrowhead in $A$ and $B$, vagus nerve; double black arrowheads in $G$ and $H$, mandibular branch of the trigeminal nerve; black arrow, maxillary branch; large black arrowhead in $E$ and $F$, vestibular ganglion. Magnifications, $\times 10(A-D) ; \times 4(E-H)$. See note in the legend of Figure 4.

neuronal populations decorated by the peripherin antiserum. Moreover, in contrast to what we had observed with biochemical methods, the immunohistochemical data presented here clearly point out that the well-defined neuronal populations in which peripherin is expressed belong to distinct lineages and have different functions.

Our earlier finding with biochemical methods (Portier et al., 1984b) that peripherin expression is quantitatively important 


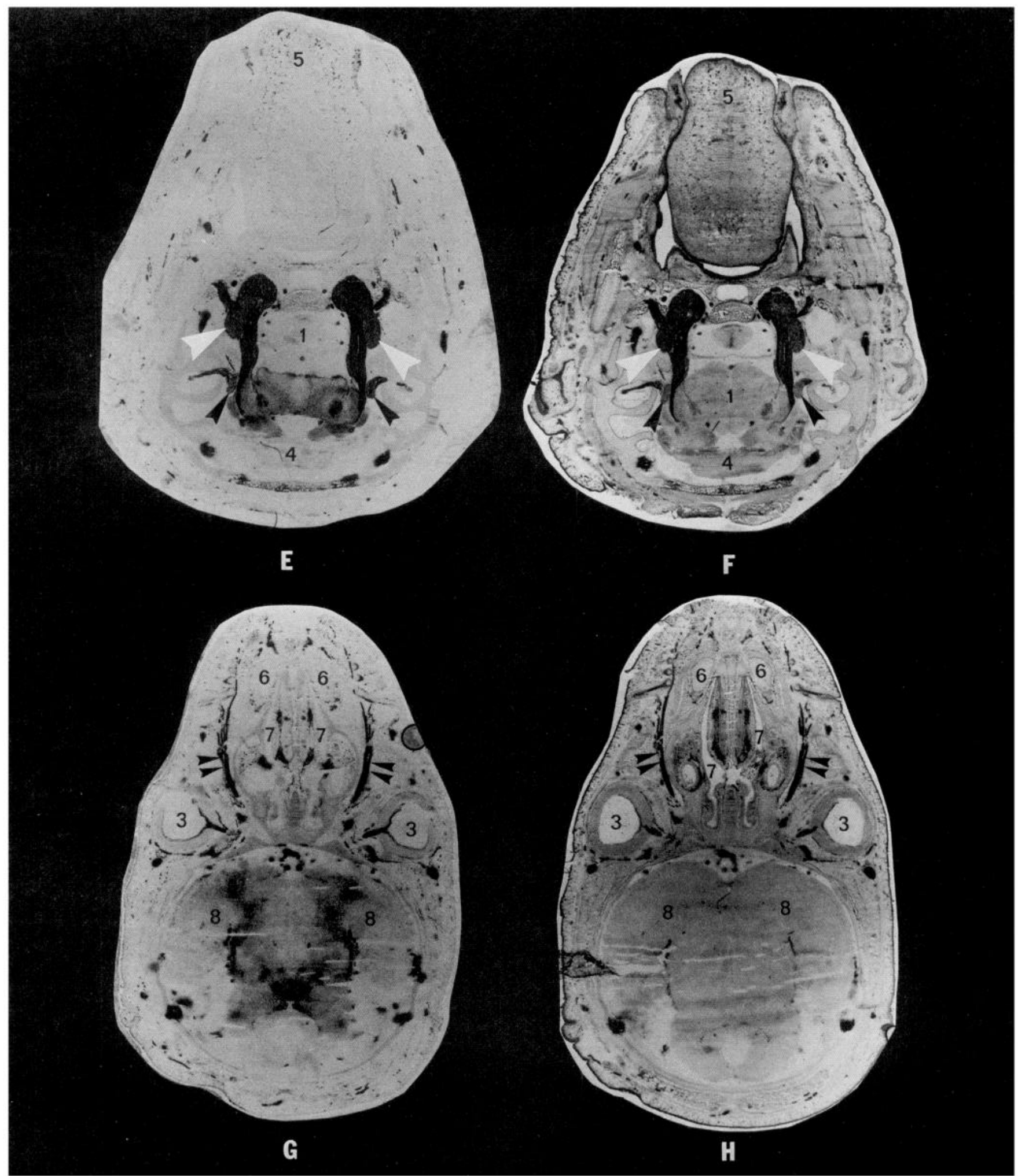

Figure 9. Continued.

in the autonomous nervous system and in the dorsal root ganglia is perfectly corroborated. In those studies, it was possible to analyze this expression quantitatively in dorsal root ganglia and to show that the incorporation of ${ }^{35} \mathrm{~S}$-methionine into both peripherin and NF-L increases during the development and prob- ably also during the differentiation of these ganglia. Moreover, it is clear that concerning the neurons from the autonomous nervous system and the dorsal root ganglia, all of which originate from migrating neural crest cells, the immunoreactivities of peripherin and of NF-L become apparent only when they have 

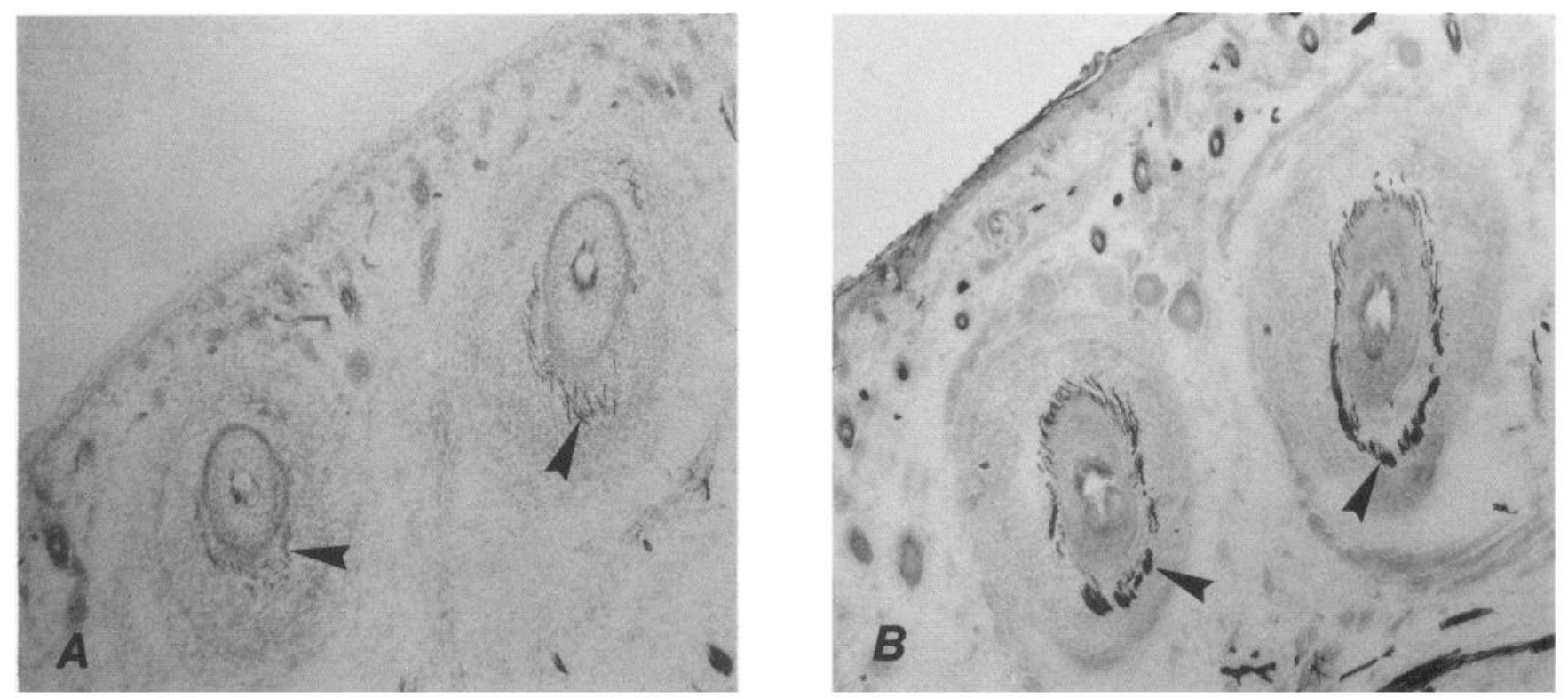

Figure 10. Innervation of the vibrissae. Parts of transverse sections of the head of a 3-d-old rat were decorated with the mAb to NF-L ( $A$ ) and the peripherin antiserum $(B)$ as in the preceding figures. Arrowheads point to the nervous fibers. Magnification, $\times 75$. See note in the legend of Figure 4.

reached their destination. This finding is in perfect agreement with the conclusion drawn by Le Douarin (1982), who considered that "one feature of the development of neural crest cells is that they start differentiating only after a phase of migration which brings them to a defined embryonic region."

The expression of peripherin in the motoneurons of the spinal cord had not been detected on 2-dimensional Coomassie bluestained gels (Portier et al., 1984b); although peripherin is also present in the sensory dorsal fibers of the spinal cord, we were unable to detect this protein in total extracts from the spinal cord by biochemical methods. This expression is only revealed by immunohistochemical methods; it has already been demonstrated by these same methods (Parysek and Goldman, 1988) and also by hybridization in situ (Leonard et al., 1988; Parysek et al., 1988).

The new results brought out by immunnhistochemical methods bear on peripherin expression in autonomic preganglionic neurons and in sensory neurons which are not derived from the neural crest but from the neural tube (retinal ganglion cells) or from placodes which are thickenings of defined parts of the ectoblast (olfactory neurons and neurons from the acoustic ganglia).

Interestingly, autonomic preganglionic neurons, which interact with ganglionic neurons, express peripherin. As the motoneurons they originate from the neural tube and their axons leave the spinal cord through the ventral root, before heading for the sympathetic ganglia.

Optic vesicles originate from the neural tube; they first bulge out ventrolaterally from each side of the forebrain; invagination of these vesicles leads to the formation of 2 cell layers, one of which gives rise to the retina (reviewed by Barnstable, 1987). Neurofilament proteins are expressed in retinal ganglion cells, and their network has been extensively studied in these cells (Nixon and Logvinenko, 1986; Lewis and Nixon, 1988; Nixon et al., 1989); they are also present in the axonless horizontal cells of the retina and may be coexpressed there with vimentin, which is usually absent from adult neurons (Dräger, 1983; Shaw and Weber, 1983). The expression of peripherin in the retina was unexpected and would not have been visualized but for the transverse sections through the eyes and the optic nerves. Peripherin being present in the optic nerve, we can deduce that the decoration of retina by the peripherin antiserum concerns the retinal ganglion cells. We have no evidence for the expression or nonexpression of this protein in the axonless horizontal cells.

It has been shown that the differentiation of the olfactory placode leads to the formation of the olfactory epithelium, which is composed of 3 different types of cells (reviewed by Graziadei, 1971): (1) the basal cells, which are directly in contact with the basement membrane; these cuboidal cells are considered neurogenic stem cells capable of dividing and differentiating into sensory cells; (2) the sustentacular cells, which resemble glia; (3) the sensory cells, which are bipolar neurons projecting toward the nasal cavity a dendritic process bearing at its tip 5-20 cilia and extending an unmyelinated axon toward the olfactory bulb; these axons group into nerve bundles that synapse in the olfactory bulb before being relayed to the olfactory cortex (Shepherd, 1972). As to the expression of IFP, Vollrath et al. (1985) observed that none of the antibodies to IFP decorated the sensory neurons of the olfactory epithelium and proposed that the olfactory sensory neurons are not postmitotic as other neurons are, but constantly renew (Graziadei and Monti-Graziadei, 1979a, b). However, Schwob et al. (1986) demonstrated that the majority of olfactory neurons and their axons contain vimentin or a protein of similar immunological character and electrophoretic mobility. Since our peripherin antiserum does not cross-react with vimentin, this could mean that peripherin is coexpressed with vimentin in the olfactory neurons or that peripherin cross-reacts with the vimentin $\mathrm{mAb}$ that these authors used. They concluded that the olfactory epithelium retains an important juvenile biological function and that its neurons express a protein characteristic of neuronal precursors and young neurons. Considering the disagreement between the authors who studied the expression of IFP in the olfactory neurons (Vollrath et al., 1985; Schwob et al., 1986; Talamo et al., 1989), it will be important to reconsider the problem. If peripherin is really the only IFP to be expressed there, it would be the only case 

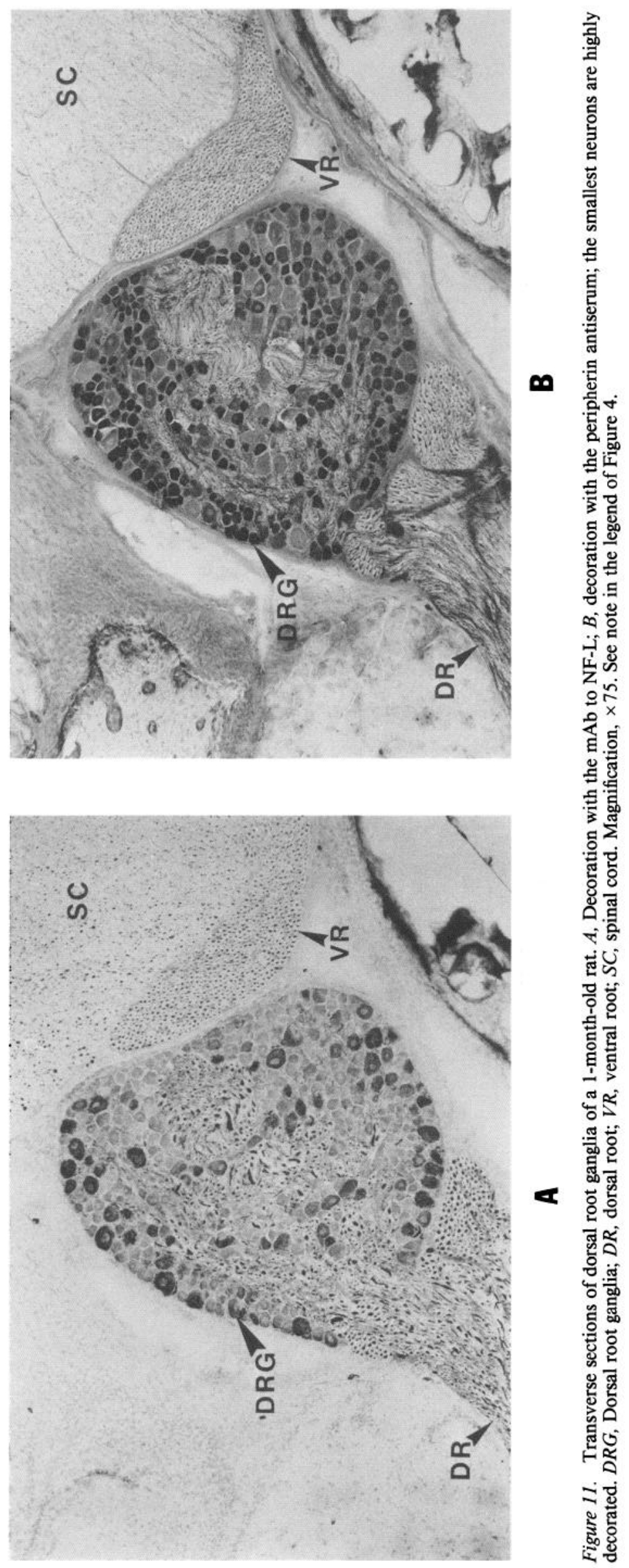


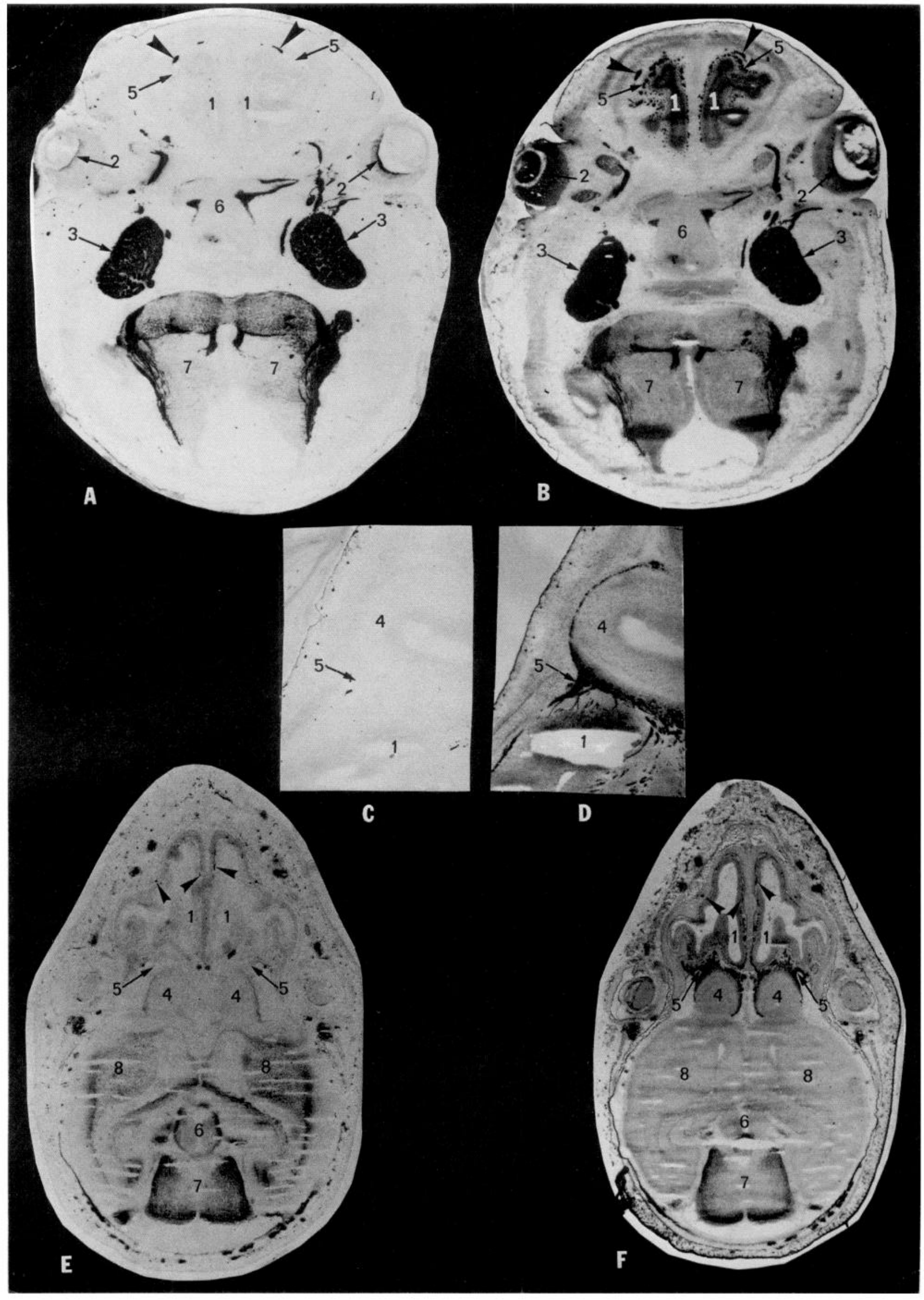


Table 1. Expression of NF-L and peripherin in sensory neurons during the development of the rat

Origin and localization of sensory neurons

Neural crest:

dorsal root ganglia and part

Neural tube:

of cranial nerve ganglia

retina and optic nerves $\quad$ Placodes

\begin{tabular}{|c|c|c|c|c|c|c|c|c|}
\hline \multirow{3}{*}{$\begin{array}{l}\text { Age of } \\
\text { embryos }\end{array}$} & & & & \multirow{2}{*}{\multicolumn{2}{|c|}{ Olfactory axons }} & \multirow{2}{*}{\multicolumn{2}{|c|}{ Acoustic ganglia }} \\
\hline & \multirow[b]{2}{*}{ NF-I } & \multirow[b]{2}{*}{ PE } & \multirow[b]{2}{*}{ NF-L } & \multirow[b]{2}{*}{ PE } & & & & \\
\hline & & & & & NF-L & PE & NF-L & $\mathrm{PE}$ \\
\hline $10 \mathrm{~d}$ (15 somites) & - & - & - & - & - & - & - & - \\
\hline $11 \mathrm{~d}$ (25 somites) & $\begin{array}{l}\text { Trigeminal } \\
\text { nerves }\end{array}$ & - & - & - & - & - & - & - \\
\hline $12 \mathrm{~d}$ (34 somites) & \multicolumn{2}{|c|}{$\begin{array}{l}\text { Trigeminal nerves } \\
\text { Cervical and thoracic ganglia } \\
\text { (cell bodies and axons) }\end{array}$} & - & - & - & - & - & - \\
\hline $13 \mathrm{~d}$ & \multicolumn{2}{|c|}{$\begin{array}{l}\text { Lumbosacral ganglia } \\
\text { Plexuses: } \\
\text { brachial and lumbosacral }\end{array}$} & - & - & - & - & + & + \\
\hline $14 \mathrm{~d}$ & \multicolumn{2}{|c|}{$\begin{array}{l}\text { Every ganglion (cell bodies and } \\
\text { axons) is immunoreactive }\end{array}$} & - & - & - & - & + & + \\
\hline $15 \mathrm{~d}$ & + & + & \multicolumn{2}{|c|}{ Retina } & - & + & + & + \\
\hline $16 \mathrm{~d}$ & + & + & \multicolumn{2}{|c|}{ Optic nerves } & - & + & + & + \\
\hline $19 \mathrm{~d}$ & + & + & + & + & - & + & + & + \\
\hline 1 week & + & + & + & + & - & + & + & + \\
\hline 1 month & + & + & + & + & ND & ND & ND & ND \\
\hline
\end{tabular}

ND, not determined.

where it is expressed alone, since we know that it is coexpressed with vimentin in mouse neuroblastoma cell lines (Portier et al., 1984a), with NFP in PC12 (Franke et al., 1986) and in the neuronal cell populations where it is expressed (Djabali, unpublished observations).

A last point concerning the sensory neurons relates to the acoustic ganglia, whose origin has long been a matter of controversy (Halley, 1955; Batten, 1958; Deol, 1967, 1970; D'Amico-Martel and Noden, 1983). More recently, Raphael et al. (1987) found that cytokeratins are transiently expressed in the future neurons of these ganglia during the embryonic development and came to the conclusion that this could be a proof that they originate from the otic placode as the cochlear epithelium which includes sensory cells (Sher, 1971; Rubel, 1978; Romand, 1988). We detected immunoreactivities of NF-L and of peripherin in the acoustic ganglia at E 13, later than in cervical and thoracic dorsal root ganglia but earlier than in the olfactory nerve fibers. On the one hand, considering the hypothesis of a neural crest origin, it is surprising that immunoreactivities do not appear at the same time as in the other ganglia, and on the other, the possibility of a placodal origin for neurons exists since this is so in the olfactory epithelium.

Our biochemical and immunohistochemical results can be summarized as follows: (1) peripherin is not expressed in most neurons of the CNS; (2) peripherin is expressed together with NF-L (and then probably with the 2 other NFP) either in neurons from the same origin but with different functions (motoneurons, autonomic preganglionic neurons and ganglionic cells of the retina originating from the neural tube, sensory neurons of the dorsal root ganglia and sympathetic neurons from the neural crest) or in neurons from different origins (neural tube, neural crest, placodes) but with the same functions (the diverse sensory neurons); (3) peripherin either is the only IFP expressed in the olfactory neurons or is coexpressed there with vimentin.

When one looks for possible common points to all these neurons expressing peripherin, it is obvious that, since the neurotransmitters are different in the neuronal populations expressing peripherin, no correlation can be seen between the neurotransmitter and peripherin expression. However, one common point emerges: the pathways of the axons are at least partially outside the CNS. Other studies (Djabali et al., unpublished observations) show that peripherin and NFL are coexpressed in every neuron of primary cultures either from the dorsal root ganglia or from the sympathetic ganglia; this means that peripherin expression is a general feature of the diverse classes of neurons that we have listed under (2) and do not allow to differentiate either among neuronal types in the autonomous nervous system or among the sensory neurons. From the localization of the phosphorylated sites on the amino-terminal part of its molecule (Huc et al., 1989), from the nucleotide sequence of cDNAs encoding either rat or mouse peripherin (Leonard et al., 1988; Parysek et al., 1988; Landon et al., 1989), and from the sequence of the rat peripherin gene (Thompson and Ziff, 1989), this protein is a type III IFP, as vimentin and desmin are; these 2 proteins have been found to be linked to the nuclear membrane through lamin B by their carboxy-terminal end and to the plasmic mem-

\footnotetext{
Figure 12. Expression of peripherin in the olfactory nerve fibers. This expression is well apparent on transverse sections at $\mathrm{E} 16(B$, through $e-f$ in Fig. 2) and at D $7(D$, through $a-b$ in Fig. 2): 5. Arrowheads point out sections of fibers from the trigeminal nerves. $A(\mathrm{E} 16), C(\mathrm{E} 18)$, and $E$ (D 7) show that no immunoreactivity to NF-L can be detected at the location of the olfactory nerve fibers except in fibers belonging to the trigeminal nerve. $C$ and $D$ are enlarged portions of a sagittal section of the nasal cavity and the olfactory bulb at $E$ 18. 1, Nasal cavity; 2, retina; 3, semilunar ganglion; 4 , olfactory bulb; 5 , olfactory nerve and fibers; 6 , diencephalon; 7 , myelencephalon; 8 , telencephalon. Magnifications, $\times 14(A$ and $B$ ); $\times 40(C$ and $D) ; \times 4(E$ and $F)$. See note in the legend of Figure 4.
} 

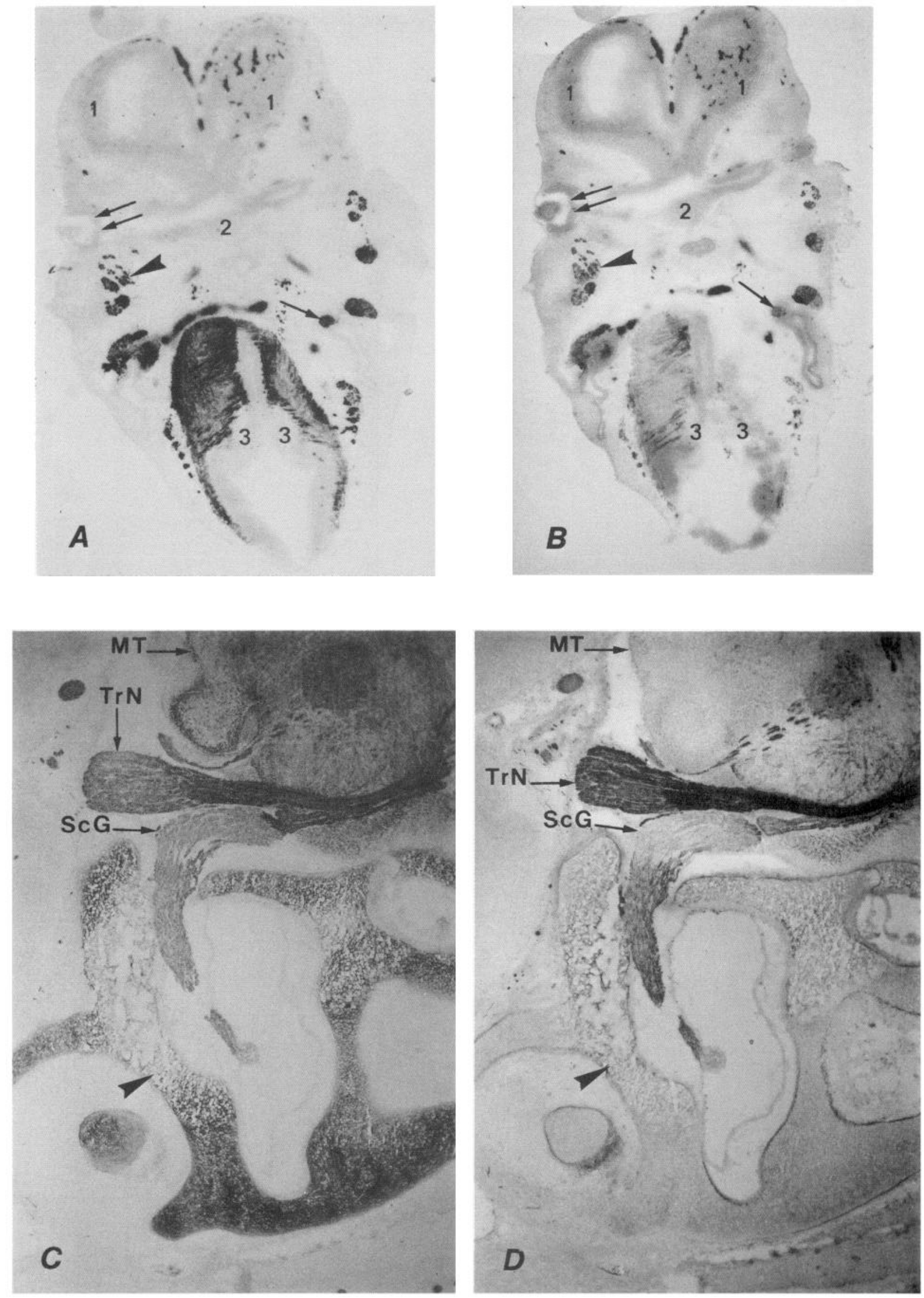


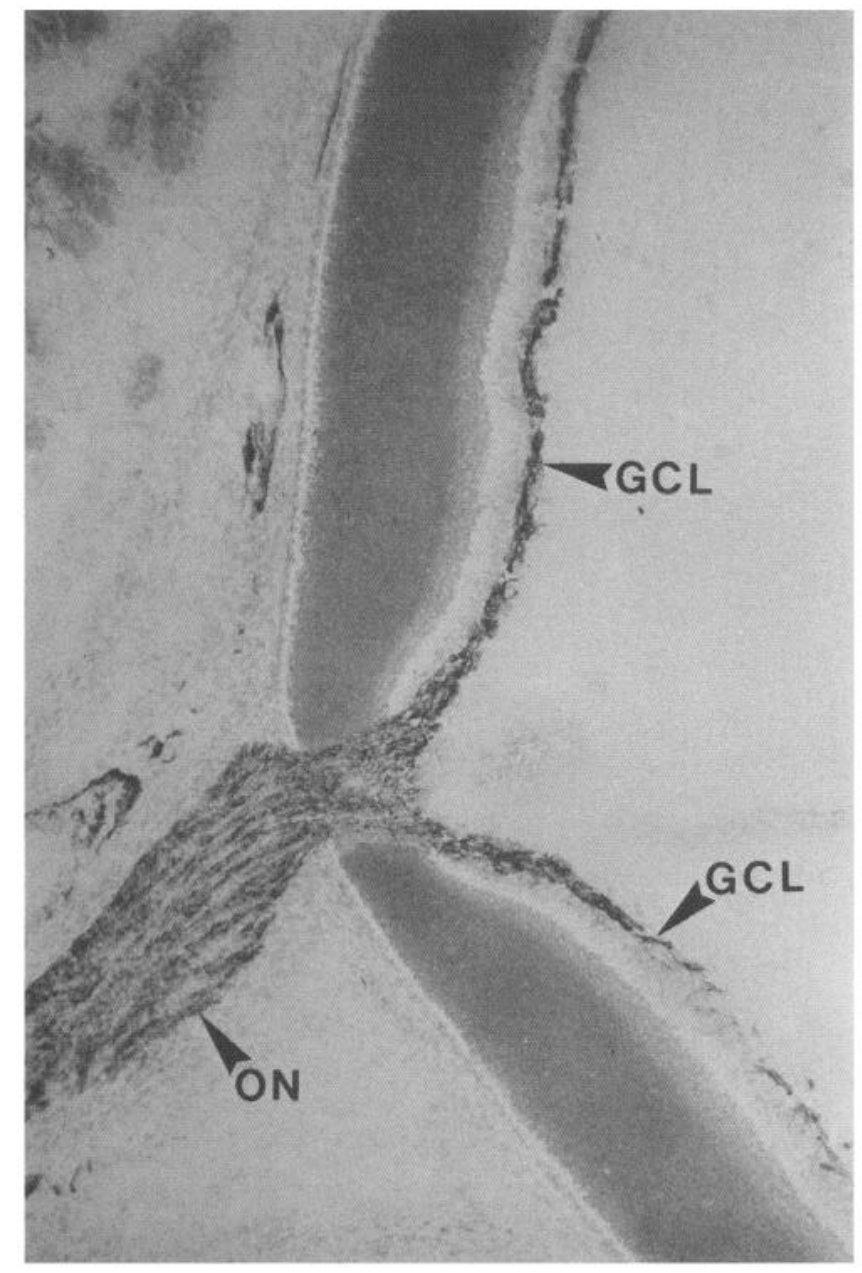

A

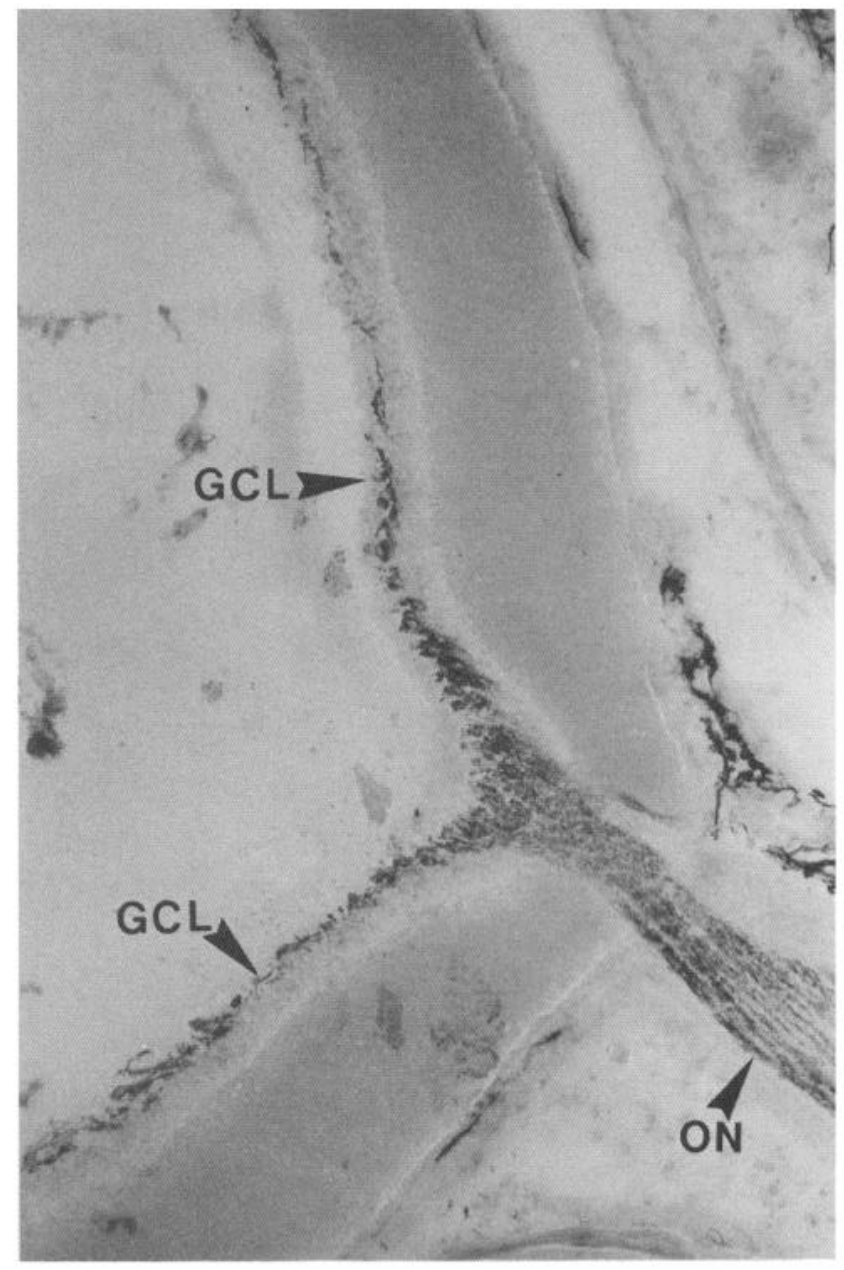

B

Figure 14. Transverse sections of the retina of a 3-d-old rat. The sections were decorated with the mAb to NF-L $(A)$ and the pAb to peripherin $(B)$. GCL, Ganglionic cell layer; $O N$, optic nerve. Magnification, $\times 75$. See note in the legend of Figure 4.

brane through ankyrin by their amino-terminal end (Georgatos and Marchesi, 1985; Georgatos et al., 1985, 1987; Georgatos and Blobel, 1987). This raises the question of the arrangement of peripherin with NFP, which are type IV IFP, in the neurons where they are coexpressed and also of the network formed by peripherin either alone or with vimentin in the olfactory neurons. Has peripherin a role in the axonal transport, or if it is linked to the plasmic membrane, as vimentin and desmin, does it allow the recognition of the pathway through specific membrane proteins (whose existence remains to be demonstrated) after having been expressed in response to an external stimulus? The existence and the nature of the specific membrane proteins, their tissue localization, their synthesis, and transfer of information through the membrane remain to be elucidated. Experiments are in progress in our laboratory in order to explore these different questions.

\section{References}

Aletta, J. M., R. Angeletti, R. K. H. Liem, C. Purcell, M. L. Shelanski, and L. A. Greene (1988) Relationship between the nerve growth factor-regulated clone 73 gene product and the 58-kilodalton neuronal intermediate filament protein (peripherin). J. Neurochem. 51:13171320.

Barnstable, C. J. (1987) A molecular view of vertebrate retinal development. Mol. Neurobiol. 1: 9-46.

Batten, E. H. (1958) The origin of the acoustic ganglion in the sheep. J. Embryol. Exp. Morph. 6: 597-615.

Bignami, A., L. P. Kozar, and D. Dahl (1980) Molecular markers for the analysis of neural differentiation in culture. In Tissue Culture in Neurobiology, E. Giacobini, A. Vernadakis, and A. Shahar, eds., pp. 63-74, Raven, New York.

Bignami, A., T. Raju, and D. Dahl (1982) Localization of vimentin, the nonspecific intermediate filament protein, in embryonic glia and in early differentiating neurons. Dev. Biol. 91: 286-295.

Cochard, P., and D. Paulin (1984) Initial expression of neurofilaments

Figure 13. Expression of NF-L and peripherin in vestibular ganglia. Transverse sections of E 13 embryos (through $g-h$ in Fig. 2 ) were immunostained with the mAb to NF-L $(A)$ and the pAb to peripherin $(B)$. Both proteins are expressed in the myelencephalon and in some ganglia: vestibular (arrows) and semilunar (arrowheads). Moreover, optic cups that have been pinched off the cavity of the diencephalon to form the optic stalks are quite visible (double arrows). No expression of either protein can yet be detected in the retina or of NF-L in the diencephalon and the telencephalon. $I$, Telencephalon; 2 , diencephalon; 3 , myelencephalon. Note some blood deposits in the telencephalon. Magnification, $\times 25$. Transverse sections of the area of the vestibular ganglion in 1-week-old animals $(C$ and $D)$ were decorated as in $A(C)$ and $B(D)$ and photographed at a higher magnification. $S c G$, Scarpa or vestibular ganglion; $\operatorname{TrN}$, part of the trigeminal nerve; $M T$, metencephalon. Black arrowhead, bone of the otic capsule. Magnification, $\times 75$. See note in the legend of Figure 4. 


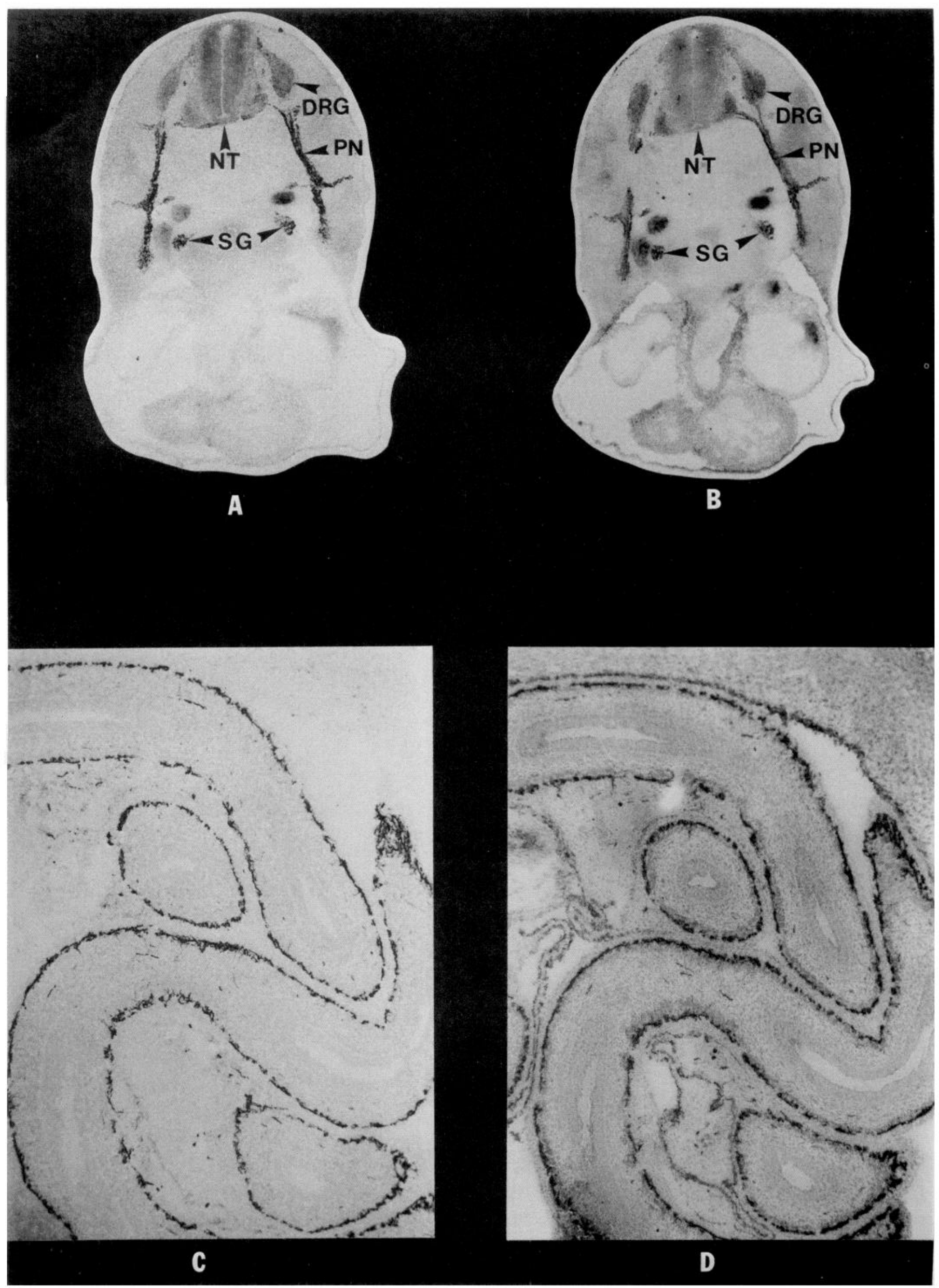



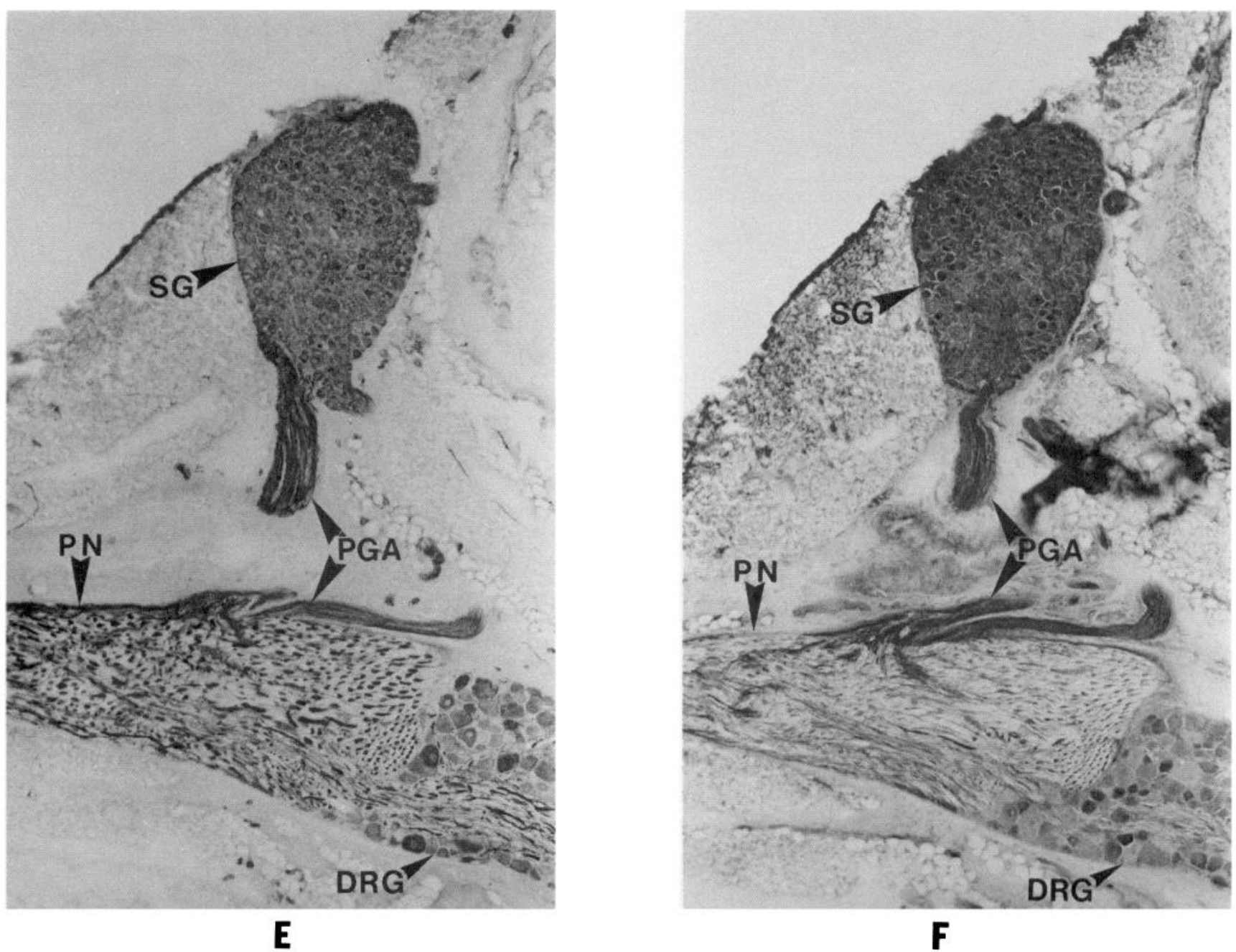

Figure 15. Expression of NF-L and peripherin in the autonomous nervous system. Transverse sections of a 44-somite embryo were immunostained with the mAb to NF-L $(A)$ and the pAb to peripherin $(B)$. Both antibodies decorate the sympathetic ganglia. Decoration of intestinal loops has already been seen in Figure $8 . C$ and $D$ are photographs at higher magnification of the immunoreactivities, respectively, to mAb and to pAb at $\mathrm{E}$ 18. $E$ and $F$ show the immunoreactivity to both antibodies $(E, \mathrm{mAb} F, \mathrm{pAb})$ on 2 strictly adjacent sections of the preganglionic axons coming from the neurons located in the intermediolateral cell column and of the sympathetic ganglia. $P G A$, Preganglionic axons; $S G$, sympathetic ganglion; $P N$, peripheral nerve; $D R G$, dorsal root ganglion. Magnifications, $\times 30(A$ and $B) ; \times 75(C-F)$. See note in the legend of Figure 4.

and vimentin in the central and peripheral nervous system of the mouse embryo in vivo. J. Neurosci. 4: 2080-2094.

Croizat, B., F. Berthelot, B. Ferrandes, P. Eymard, C. Sahuquillo, and F. Gros (1977) Differenciation morphologique du neuroblastome par l'acide I méthyl cyclohexane carboxylique (CCA) et certains dérivés en C 1. C.R. Acad. Sci. Paris 289 (série D): 1283-1286.

Dahl, D., and A. Bignami (1986) Neurofilament phosphorylation in development: A sign of axonal maturation? Exp. Cell Res. 162: 220 230.

D'Amico-Martel, A., and D. M. Noden (1983) Contributions of placodal and neural crest cells to avian peripheral ganglia. Am. J. Anat. 166: $445-468$.

Deol, M. S. (1967) The neural crest and the acoustic ganglion. J. Embryol. Exp. Morph. 17: 533-541.

Deol, M. S. (1970) The origin of the acoustic ganglion and effects of the gene dominant spotting (Wv) in the mouse. J. Embryol. Exp. Morph. 23: 773-784.

Dräger, V. C. (1983) Coexistence of neurofilaments and vimentin in a neuron of adult mouse retina. Nature 303: 169-172.

Eddé, B., M.-M. Portier, C. Sahuquillo, C. Jeantet, and F. Gros (1982) Changes in some cytoskeletal proteins during neuroblastoma differentiation. Biochimie 64: 141-151.

Escurat, M., M. Gumpel, F. Lachapelle, F. Gros, and M.-M. Portier (1988a) Comparative study of the expression of two intermediate filament proteins, peripherin and the $68 \mathrm{kDa}$ neurofilament protein, during the development of the rat embryo. C.R. Acad. Sci. Paris 306 (série III): $447-456$.
Escurat, M., F. Landon, M. Gumpel, F. Gros, and M.-M. Portier(1988b) Peripherin, an intermediate filament protein, is a developmental marker of specific neuronal populations. In Structure and Functions of the Cytoskeleton, B. A. F. Rousset, ed., pp. 169-177, Colloque INSERM, John Libbey Eurotext.

Franke, W. W., E. Schmid, D. L. Schiller, S. Winter, E. D. Jarasch, R. Moll, H. Denk, B. W. Jackson, and K. Illmensee (1982) Differentiation-related patterns of expression of proteins of intermediate-size filaments in tissues and cultured cells. Cold Spring Harbor Symp. Quant. Biol. 46: 431-454.

Franke, W. W., C. Grund, and T. Achstätter (1986) Co-expression of cytokeratins and neurofilaments proteins in a permanent cell line: Cultured rat PC12 cells combine neuronal and epithelial features. J. Cell Biol. 103: 1933-1943.

Georgatos, S. D., and G. Blobel (1987) Lamin B constitutes an intermediate filament attachment site at the nuclear envelope. Proc. Natl. Acad. Sci. USA 105: 117-125.

Georgatos, S. D., and V. T. Marchesi (1985) The binding of vimentin to human erythrocyte membranes: A model system for the study of intermediate filament-membrane interactions. J. Cell Biol. 100: 19551961.

Georgatos, S. D., D. C. Weaver, and V. T. Marchesi (1985) Site specificity in vimentin-membrane interactions: Intermediate filament subunits associate with the plasma membrane via their head domains. J. Cell Biol. 100: 1962-1967.

Georgatos, S. D., K. Weber, N. Geisler, and G. Blobel (1987) Binding of two desmin derivatives to the plasma membrane and the nuclear 
envelope of avian erythrocytes: Evidence for a conserved site-specificity in intermediate filament-membrane interactions. Proc. Natl. Acad. Sci. USA 84: 6780-6784.

Graziadei, P. P. C. (1971) The olfactory mucosa of vertebrates. In Handbook of Sensory Physiology, vol. 4, Chemical Senses. I. Olfaction, L. M. Beidler, ed., pp. 27-58, Springer, New York.

Graziadei, P. P. C. and G. A. Monti-Graziadei (1979a) Neurogenesis and neuron regeneration in the olfactory system of mammals. I. Morphological aspects of differentiation and structural organization of the olfactory sensory organ. J. Neurocytol. 8: 1-18.

Graziadei, P. P. C., and G. A. Monti-Graziadei (1979b) Neurogenesis and neuron regeneration in the olfactory system of mammals. II. Degeneration and reconstitution of the olfactory sensory neurons after axotomy. J. Neurocytol. 8: 197-213.

Greene, L. (1989) A new neuronal intermediate filament protein. Trends Neurosci. $12: 228-230$.

Halley, G. (1955) The placodal relations of the neural crest in the domestic cat. J. Anat. (Lond.) 89: 133-152.

Hirokawa, N., M. A. Glicksman, and M. B. Willard (1984) Organization of mammalian neurofilament polypeptides within the neuronal cytoskeleton. J. Cell Biol. 98: 1523-1536.

Hoffman, P. N., and R. J. Lasek (1975) The slow component of axonal transport. Identification of major structural polypeptides of the axon and their generality among mammalian neurons. J. Cell Biol. 66: 35l-366.

Holtzer, H., G. S. Bennett, S. J. Tapscott, J. M. Croop, and Y. Toyama (1982) Intermediate-size filaments: Changes in synthesis and distribution in cells of the myogenic and neurogenic lineages. Cold Spring Harbor Symp. Quant. Biol. 46: 317-330.

Huc, C., M. Escurat, K. Djabali, M. Derer, F. Landon, F. Gros, and M. M. Portier (1989) Phosphorylation of peripherin, an intermediate filament protein, in mouse neuroblastoma NIE 115 cell line and in sympathetic neurons. Biochem. Biophys. Res. Commun. 160: 772779.

Landon, F., M. Lemonnier, M. Benarous, C. Huc, M. Fiszman, F. Gros, and M. M. Portier (1989) Multiple mRNAs encode peripherin, a neuronal intermediate filament protein. EMBO J. 8: 1719-1726.

Lazarides, E. (1980) Intermediate filaments as mechanical integrators of cellular space. Nature 283: 249-256.

Le Douarin, N. M. (1982) The Neural Crest, Cambridge U.P., London.

Leonard, D. G. B., J. D. Gorham, P. Cole, L. A. Greene, and E. B. Ziff (1988) A nerve growth factor-regulated messenger RNA encodes a new intermediate filament protein. J. Cell Biol. 106: 181-193.

Lewis, S. E., and R. A. Nixon (1988) Multiple phosphorylatcd variants of high molecular mass subunit of neurofilaments in axons of retinal cell neurons: Characterization and evidence for their differential association with stationary and moving neurofilaments. J. Cell Biol. 107: 2689-2701.

Liem, R. K. H., S.-H. Yen, G. D. Salomon, and M. J. Shelanski (1978) Intermediate filaments in nervous tissues. J. Cell Biol. 79: 637-645.

Nixon, R. A., and K. B. Logvinenko (1986) Multiple fates of newly synthesized neurofilament proteins: Evidence for a stationary neurofilament network distributed nonuniformly along axons of retinal ganglion cell neurons. J. Cell Biol. 102: 647-659.

Nixon, R. A., S. E. Lewis, D. Dahl, C. A. Marotta, and U. C. Drager (1989) Early posttranslational modifications of the three neurofilament subunits in mouse retinal ganglion cells: Neuronal sites and time course in relation to subunit polymcrization and axonal transport. Mol. Brain Res. 5: 93-108.

O'Farrell, P. H. (1975) High resolution two-dimensional electrophoresis of proteins. J. Biol. Chem. 250: 4007-4021.

Parysek, L. M., and R. D. Goldman (1987) Characterization of intermediate filaments in PC12 cells. J. Neurosci. 7: 781-791.

Parysek, L. M., and R. D. Goldman (1988) Distribution of a novel $57 \mathrm{kDa}$ intermediate filament (IF) protein in the nervous system. J. Neurosci. 8: 555-563.

Parysek, L. M., R. L. Chisholm, C. A. Ley, and R. D. Goldman (1988) A type III intermediate filament gene is expressed in mature neurons. Neuron $1: 395-401$.
Portier, M. M., P. Brachet, B. Croizat, and F. Gros (1984a) Regulation of peripherin in mouse neuroblastoma and rat $\mathrm{PC} 12$ pheochromocytoma cell lines. Dev. Neurosci. 6: 215-226.

Portier, M.-M., B. de Néchaud, and F. Gros (1984b) Peripherin, a new member of the intermediate filament protein family. Dev. Neurosci. 6: 335-344.

Pruss, R. M., R. Mirsky, M. C. Raff, R. Thorpe, A. J. Dowding, and B. H. Anderton (1981) All classes of intermediate filaments share a common antigenic determinant defined by a monoclonal antibody. Cell 27: 419-428

Raju, T., A. Bignami, and D. Dahl (1981) In vivo and in vitro differentiation of neurons and astrocytes in the rat embryo: Immunofluorescence study with neurofilament and glial filament antisera. Dev. Biol. 85: 344-357.

Raphael, Y., G. Marshak, A. Barash, and B. Geiger (1987) Modulation of intermediate-filament expression in developing cochlear epithelium. Differentiation 35: 151-162.

Romand, R. (1988) Development of the cochlea. In Development of Auditory and Vestibular Systems, R. Romand, ed., pp. 47-88, Academic, New York.

Rubel, E. W (1978) Ontogeny of structure and function in the vertebrate auditory system. In Handbook of Sensory Physiology, vol. IX, Development of Sensory Systems, M. Jacobson, ed., pp. 135-237, Springer, New York.

Schlaepfer, W. W., and L. A. Freeman (1978) Neurofilament proteins of rat peripheral nerve and spinal cord. J. Cell Biol. 78: 653-662.

Schwob, J. E., N. B. Farber, and D. I. Gottlieb (1986) Neurons of the olfactory epithelium in adult rats contain vimentin. J. Neurosci. 6: 208-217.

Scott, D., K. E. Smith, B. J. O'Brien, and K. J. Angelides (1985) Characterization of mammalian neurofilament triplet proteins. Subunit stoichiometry and morphology of native and reconstituted filaments. J. Biol. Chem. 260: 10736-10747.

Sharp, G. A., G. Shaw, and K. Weber (1982) Immunoelectron-microscopical localization of the three neurofilament proteins along neurofilaments in cultured dorsal root ganglion cells. Exp. Cell Res. 137: $403-413$.

Shaw, G., and K. Weber (1983) The structure and development of the rat retina: An immunofluorescence microscopical study using antibodies specific for intermediate filament proteins. Eur. J. Cell Biol. 30: 219-232.

Shepherd, G. M. (1972) Synaptic organization of the mammalian olfactory bulb. Physiol. Rev. 52: 864-917.

Sher, A. E. (1971) The embryonic and postnatal development of the inner ear of the mouse. Acta Otolaryngol. (Suppl.) 285: 1-77.

Talamo, B. R., R. A. Rudel, K. S. Kosik, V. M.-Y. Lee, S. Neff, L. Adelman, and J. S. Kauer. (1989) Pathological changes in olfactory neurons in patients with Alzheimer's disease. Nature 337: 736-739.

Tapscott, S. J., G. S. Bennett, and H. Holtzer (1981a) Neuronal precursor cells in the chick neural tube express neurofilament proteins. Nature 292: 836-838.

Tapscott, S. J., G. S. Bennett, Y. Toyama, F. Kleinbart, and H. Holtzer (1981 b) Intermediate filament proteins in the developing chick spinal cord. Dev. Biol. 86: 40-54.

Thompson, M. A., and E. B. Ziff (1989) Structure of the gene encoding peripherin, an NGF-regulated neuronal-specific type III intermediate filament protein. Neuron 2: 1043-1053.

Ticrcy, J.-M., and E. M. Shooter (1986) Early changes in the synthesis of nuclear and cytoplasmic proteins are induced by nerve growth factor in differentiating rat PC12 cells. J. Cell Biol. 103: 2367-2378.

Vollrath, M., M. Altmannsberger, K. Weber, and M. Osborn (1985) An ultrastructural and immunohistological study of the rat olfactory epithelium: Unique properties of olfactory sensory cells. Differentiation 29: 243-253.

Willard, M., and C. Simon (1981) Antibody decoration of neurofilaments. J. Cell Biol. 89: 198-205. 